Tarunabh Khaitan*

\title{
Killing a Constitution with a Thousand Cuts: Executive Aggrandizement and Party-state Fusion in India
}

https://doi.org/10.1515/lehr-2020-2009

\begin{abstract}
Many concerned citizens, including judges, bureaucrats, politicians, activists, journalists, and academics, have been claiming that Indian democracy has been imperilled under the premiership of Narendra Modi, which began in 2014. To examine this claim, the Article sets up an analytic framework for accountability mechanisms liberal democratic constitutions put in place to provide a check on the political executive. The assumption is that only if this framework is dismantled in a systemic manner can we claim that democracy itself is in peril. This framework helps distinguish between actions that one may disagree with ideologically but are nonetheless permitted by an elected government, from actions that strike at the heart of liberal democratic constitutionalism. Liberal democratic constitutions typically adopt three ways of making accountability demands on the political executive: vertically, by demanding electoral accountability to the people; horizontally, by subjecting it to accountability demands of other state institutions like the judiciary and fourth branch institutions; and diagonally, by requiring discursive accountability by the media, the academy, and civil society. This framework assures democracy over time - i.e. it guarantees democratic governance not only to the people today, but to all future peoples of India. Each elected government has the mandate to implement its policies over a wide range of matters. However, seeking to entrench the ruling party's stranglehold on power in ways that are inimical to the continued operation of democracy cannot be one of them. The Article finds that the first Modi government in power between 2014 and 2019 did indeed seek to undermine each of these three strands of executive accountability. Unlike the assault on democratic norms during India Gandhi's Emergency in the 1970s, there is little evidence of a direct or full-frontal attack during this period. The Bharatiya Janata Party government's mode of operation was subtle, indirect, and incremental, but also systemic. Hence, the Article characterizes the phenomenon as "killing a constitution by a thousand cuts." The incremental assaults on
\end{abstract}

*Corresponding author: Tarunabh Khaitan, Professor of Public Law and Legal Theory, University of Oxford, Oxford, UK; Professor and ARC Future Fellow, Melbourne Law School, Melbourne Law School, Melbourne, Australia and Global Visiting Professor, New York University, New York, USA, E-mail: t.khaitan@unimelb.edu.au 
democratic governance were typically justified by a combination of a managerial rhetoric of efficiency and good governance (made plausible by the undeniable imperfection of our institutions) and a divisive rhetoric of hyper-nationalism (which brands political opponents of the party as traitors of the state). Since its resounding victory in the 2019 general elections, the Modi government appears to have moved into consolidation mode. No longer constrained by the demands of coalition partners, early signs suggest that it may abandon the incrementalist approach for a more direct assault on democratic constitutionalism.

Keywords: constitutionalism, democratic backsliding, Indian constitution, Indian democracy, democratic decay, neo-authoritarianism, populism

\section{"[W]e must ... observe the caution which John Stuart Mill has given to all who are interested in the maintenance of democracy, namely, not 'to lay their liberties at the feet of even a great man, or to trust him with powers which enable him to subvert their institutions'."}

JS Mill, ${ }^{1}$ quoted by BR Ambedkar on 25 November $1949,{ }^{2}$ requoted by sitting Chief Justice of India on Constitution Day (November 26, 2018). ${ }^{3}$

\section{Introduction}

As established democracies - such as Poland, Hungary, Turkey, Brazil, South Africa, and Israel - witness democratic deconsolidation, ${ }^{4}$ the world's largest democracy has sadly not been an exception. To be sure, there are no tanks on the streets of Delhi, nor is there an official declaration of a national emergency. Rights have not, formally, been suspended and most elections will take place on time. The mode of democratic decline in India, inasmuch as it is incremental and systemic, also seems to be following global trends of the early 21st century. ${ }^{5}$ There are key differences too, for India's experience with democratic deconsolidation has been

1 John Stuart Mill, Considerations on Representative Government 3 (Longmans, Green and Co. 1872).

2 Constituent Assembly Debates vol. 11 (Nov. 25, 1945) speech by Bhimrao RAmji AmbedKaR, 324, http://cadindia.clpr.org.in/constitution_assembly_debates/volume/11/1949-11-25?.

3 Anindita Sanyal, "Don't Lay Your Liberties at the Feet of Even a Great Man": Chief Justice, NDTV (Nov. 27, 2017), https://www.ndtv.com/india-news/constitution-day-2018-ranjan-gogoi-chiefjustice-of-india-supreme-court-dont-lay-your-liberties-at-f-1953713.

4 Constitutional DemocRacy In CRISIS? (Mark A. Graber, Sanford Levinson \& Mark Tushnet eds., 2018).

5 Tarunabh Khaitan, Executive Aggrandizement in Established Democracies: A Crisis of Liberal Democratic Constitutionalism, 17 INT’L J. ConsT. L. 342 (2019). 
different from Hungary's or Poland's. India's longer history with democracy and the relative strength of its institutions has meant that one term in office (between 2014 and 2019) was insufficient for the ruling party to establish its stranglehold on power. And yet, sufficient groundwork was laid for a successor Bharatiya Janata Party (hereinafter, the "BJP") administration toward securing its oft-repeated public hope of an "India free of the Congress Party" (the BJP's main political rival) and of ruling the country for the next 50 years. ${ }^{6}$

While there has been much discussion of executive aggrandizement and the decay of democratic controls in Indian political discourse, this Article fills a scholarly gap by offering a thick description of the events during the first term of Mr. Narendra Modi as the Prime Minister of India to evidence the phenomenon in India. In doing so, the Article takes pains to avoid castigating any permissible political agenda a right-wing party in power may seek to pursue, and focusses only on actions that - taken as a whole - imperilled the continuing operation of liberal democratic constitutionalism. The focus is not on everything that ails Indian democracy, but only on those actions of the BJP government that threatened it.

This Article shows how the first Modi government in power in India between May 2014 and May 2019 consistently sought to erase the distinction between the party and the state by incrementally, but systemically, seeking to undermine or capture mechanisms that seek executive accountability. Section I outlines three key ways in which liberal democratic constitutions make the executive accountable: vertically by demanding electoral accountability to the people, horizontally by subjecting it to accountability demands of other state institutions like the political opposition, the judiciary, and fourth branch institutions, and diagonally by requiring discursive accountability to the media, the academy, and other civil society institutions. These institutional mechanisms are undermined when their power relative to the political executive is diminished ("executive aggrandizement"). They are captured when party loyalists take over the functioning of these institutions and make them pliant to the executive ("party-state fusion").

Sections II, III, IV, and V map how the government headed by Mr. Modi incrementally and systemically undermined these three forms of accountability in its first five years in office, either by executive aggrandizement or by reducing the separation between the ruling political party and the state. These sections tend toward the descriptive - the detailed evidence they painstakingly document, however, is essential to sustain the systemicity claim made in this Article.

6 Express Web Desk, Assam in Kitty, Amit Shah Sets Eyes on Congress-Mukt 2019, INDIAN EXPRESS (May 19, 2016), https://indianexpress.com/article/india/india-news-india/assam-result-amitshah-bjp-agp-assembly-poll-result-congress-mukt-bharat/. 
This incremental fusion of the party and the state, and the erosion of mechanisms seeking executive accountability were rationalized through a discourse of hypernationalism (which equated political opposition to the party with treason), a managerial discourse that promised probity, decisiveness, and efficiency (and painted political opponents as well as checking institutions as corrupt, indecisive, or inefficient), ${ }^{7}$ and a welfarist-developmental-populist discourse that characterized procedural requirements as hurdles that got in the way of delivering development to the people.

A brief, if unavoidably simplistic, overview of the political context leading up to Narendra Modi's spectacular victory in 2014 might be helpful to readers who are less familiar with the Indian context. India became independent of British colonial rule in 1947, and in 1950 adopted a largely liberal, democratic, secular, and egalitarian Constitution. It included entrenched, judicially-enforceable, fundamental rights, a parliamentary system of government with an indirectly-elected and largely ceremonial presidency, a quasi-federal division of state power with a centralist bias, and separation of powers with a powerful and independent judiciary. Minorities of various stripes were given multiple forms of accommodation, including limited expressive accommodation of illiberal ideological groups such as Hindu nationalists. ${ }^{8}$ Until the late 1980s, India more-or-less functioned as a dominant party system, at least at the federal level. The Congress Party governed the country for most of this period, barring its disastrous, but brief, electoral punishment for the Emergency imposed by Prime Minister Indira Gandhi in the mid-70s.

The BJP, a Hindu-nationalist majoritarian party, won only two seats in the lower house of the federal Parliament in the 1984 general elections. In the 1990s, however, it rode a remarkable wave of popularity on the back of a demand for the construction of a Hindu temple on a site occupied by an Islamic mosque - the Babri Masjid - which was destroyed in late 1992, allegedly with the support and complicity of several prominent BJP leaders. It first came to power in 1998 and governed in coalition with smaller parties until 2004, under the premiership of its relatively centrist leader Mr. Atal Bihari Vajpayee. The Congress Party unexpectedly returned to power in 2004 and ruled as a coalition government under Prime Minister Manmohan Singh until 2014. During its last years, its government was mired in numerous corruption allegations, and Mr. Modi rode a powerful antiincumbency wave to form a coalition government in 2014.

Two clarifications are necessary before we begin. First, the Article suggests that something distinctive happened during the first five Modi years. The systemicity of its assaults on all accountability-seeking mechanisms made it different

7 Amrita Basu, Narendra Modi and India's Populist Democracy, 1 InDIAN PoL. \& Pol'Y 83 (2018). 8 Tarunabh Khaitan, Directive Principles and the Expressive Accommodation of Ideological Dissenters, 16 InT’L J. Const. L. 389 (2018). 
from previous governments, which had all been constitutionally naughty every now and then; the subtlety and incrementalism of its assaults distinguished it from more direct assaults on constitutionalism during the Emergency years under India Gandhi, ${ }^{9}$ the three-and-a-half decades long Communist Party rule in the state of West Bengal, ${ }^{10}$ and, possibly, even the second Modi administration elected with a full parliamentary majority for the BJP in 2019. These comparisons make clear that assaults on democracy can, and have, come from the political Left as well as the political Right.

Second, by documenting these assaults on existing constitutional mechanisms, I do not intend to suggest that the existing system was perfect. Far from it, its weaknesses, in many cases, facilitated these attacks or helped justify them. It is, in fact, a key feature of incremental authoritarianism that - like pretextual discrimination - it always rationalizes its assaults on constitutional governance on broadly accepted justifications (such as probity, efficiency, etc.). Myriad strands need attention in order to arrive at an all-things-considered judgement on the merits of each move, making it impossible for a thickly descriptive article of this sort to decide in each case whether the purported rationales were wholly pretextual, partly so, or largely legitimate. Sections II-V, therefore, document an act or attempt if one of its probable effects was executive aggrandizement or partystate fusion. Even if some of them turn out, on a fuller analysis, to be largely legitimate (despite their democratic costs), the systemicity and incrementalism of the techniques used would nonetheless be apparent. One only needs to look at the graph below based on data from the extremely reputable Varieties of Democracies Index, ${ }^{11}$ depicting India's performance on various democratic criteria since the inauguration of its Constitution in 1950 until 2019, the last year for which the data was available at the time of writing this Article.

9 P.N. DHAR, IndiRA GANDHI, THE "EMERGENCY”, AND INDIAN DEMOCRACy (2000). Most of the constitutional excesses of the Emergency were reversed by the Constitution (44th Amendment) Act 1978, enacted by the Janata Party government that came to power after defeating Indira Gandhi in the 1977 general elections.

10 Sanjeeb Mukherjee, The Use and Abuse of Democracy in West Bengal, 42 ECon. \& Pol. WkLy. 101, 101-08 (2007); Partha Sarathi Banerjee, Party, Power and Political Violence in West Bengal, 46 ECON. \& PoL. WKLY. 16, 16-18 (2011).

11 Michael Coppedge et al., V-Dem Dataset - Version 10, V-Dem: VARIETIES of Democracy (2020), https://doi.org/10.23696/vdemds20; Daniel Pemstein et al., The V-Dem Measurement Model: Latent Variable Analysis for Cross-National and Cross-Temporal Expert-Coded Data (V-Dem Working Paper No. 21, 2018), https://papers.ssrn.com/sol3/papers.cfm?abstract_ $\mathrm{id}=3167764$. See generally S.Y. Quarishi, Slipping on Democracy, INDIAN EXPRESS (Feb. 26, 2019), https://indianexpress.com/article/opinion/columns/democracy-index-economist-intelligence-unitslipping-on-democracy-5600569/. 
The two vertical lines mark the lead up to two periods of consistent decline across most markers of the health of a democracy in India: Gandhi's Emergency in 1975 and Modi's premiership in 2014. During the Emergency, democratic decline in India was across all indicators depicted below and was stark along all markers. In the Modi years, as I plan to argue, the decline has generally been less spectacular (barring the rapid decline in the independence of the Election Commission and campaign finance transparency), and evidences his incremental, but systemic, undermining of India's democracy. Thus, the social science evidence for the argument in this Article is strong, despite the caveats above. What I now propose to do is to defend the arguments with more specific evidence, organized in a clear analytic framework described in the next section.

\section{Mechanisms for Executive Accountability ${ }^{12}$}

In this section, I provide an analytic framework of the ways in which liberal democratic constitutions seek executive accountability. Przeworski famously described a democracy as a system in which parties lose elections. ${ }^{13}$ As such,

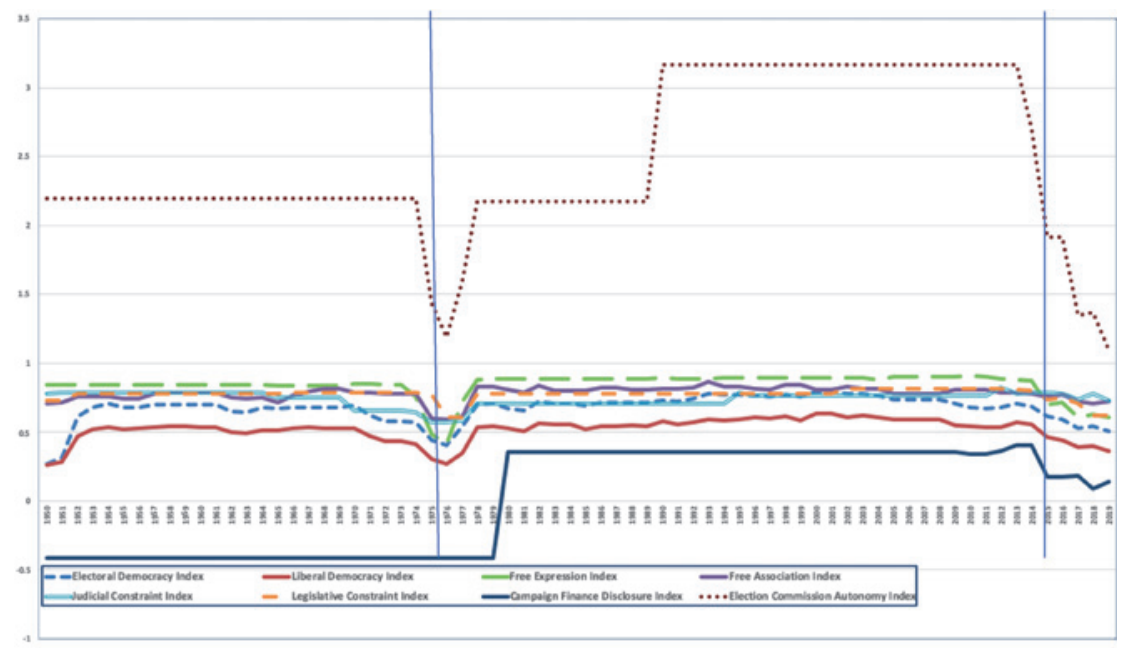

India's Year-wise V-Dem Scores between 1950 and 2019

12 This section draws heavily from Khaitan, supra note 5.

13 Adam PRZEWorski, Democracy and the Market: Political and EConomic Reforms in EASTern EUROPE AND LATIN AMERICA 10 (1991). 
democracies - at least of the representative variety - are inherently unstable systems of organizing political power in one respect: every victorious democrat has an incentive to undermine its continued operation so that she does not lose her hard-won power in the next round of elections. Alongside the military and corporate wealth, the ruling political party is one of the biggest potential sources of threat to any democracy. ${ }^{14}$ Contrast this with other regime types. An autocracy is stable in the sense that those with the most power (the autocrats) have an interest in maintaining their power. The same is true of wealth-based oligarchies or inheritance-based monarchies. It may be that these other regimes face a greater degree of external threats (external to the regime, that is, but not to the society at large). However, they are self-enforcing to the extent that they grant plenary political power to individuals and groups who are most interested in maintaining the stability of that particular regime type. The threat to a democratic regime comes from within.

The very idea of a democracy requires that every group must have genuine hope of acquiring some level of state power - at least some of the time. ${ }^{15}$ If this condition is breached, and a group in the polity is locked out of power semi-permanently, the regime is no longer a democracy. Furthermore, the stability of such a regime becomes vulnerable to external threats - those locked out of power have no reason not to try and upend it. Thus, democracies trade off internal instability for external stability, whereas other more exclusionary - regime-types are internally more stable and externally more vulnerable.

Democracies seek to protect themselves from this internal threat by creating mechanisms to ensure that those who currently enjoy political power do not foreclose the possibility of others acquiring it in their stead in the future. Although, in theory, all state power needs to be checked, it is the political executive, wielding the power of the sword, that is usually the most dangerous branch that internally threatens a democracy. Thus, the political executive is the main target of the accountability mechanisms that liberal democratic constitutions put in place.

14 See generally Tarunabh Khaitan, Political Insurance for the (Relative) Poor: Why Liberal Constitutionalism Should Resist Plutocracy, 8 Global Constitutionalism 536 (2019) (discussing wealth's threat to democracy).

15 See Samuel Issacharoff \& Richard H. Pildes, Politics as Markets: Partisan Lockups of the Democratic Process, 50 Stan. L. REv. 643 (1998). 
The purpose of this framework is to assure democracy over time - i.e., it seeks to guarantee democratic governance not only to the people today, but to all future peoples of that country. While each elected government has the mandate to implement its policies over a wide range of issues, seeking to reduce the effectiveness of these modes of accountability is best understood as an effort to entrench the ruling party's stranglehold on power in ways that are inimical to the continued operation of democracy. A democracy's accountability demands can be organized around three axes.

In the first of these axes, democracy seeks electoral - also called vertical accountability from the political executive. ${ }^{16}$ The executive is required (either directly, as in presidential systems, or indirectly, as in parliamentary systems) to periodically seek the endorsement of the people through free and fair elections. In parliamentary systems, vertical accountability can be undermined in several ways: the political executive may extend the interval between elections, remove parliament's power to vote down a government and seek new elections, or do away with the requirement that ministers must be elected representatives. Vertical accountability mechanisms can be captured by reducing the separation between the ruling party and the state through measures such as gerrymandering, electorate manipulation, vote rigging, voter disenfranchisement, biased campaign finance, and other electoral laws that give the ruling party an unfair electoral advantage over the opposition.

The threat of losing the next election often stops the executive from overreaching in ways that may not go down well with the electorate. On the other hand, this also encourages it to overreach in ways that will. In particular, electorates can sometimes be tempted to compromise their interest (and the interest of future generations) in democratic governance over the long term for (often illusory) shortterm promises. A prejudiced majority can persecute a hated minority too, often by seeking to permanently exclude it from political power. Furthermore, even for the electorate to express its will, a free and fair electoral contest is necessary - this at least needs a neutral referee and is not something one of the contestants can be trusted with. This is why most liberal constitutions tend not to be satisfied with electoral accountability alone.

The second axis of accountability for the executive is therefore institutional or horizontal. To secure this, a constitution subjects the actions of the executive to the scrutiny of several other state institutions, including a legislature, a judiciary, and various "fourth branch" institutions that include an auditor-

16 On vertical and horizontal accountability, see Guillermo O'Donnell, Horizontal Accountability in New Democracies, in The Self-Restraining State: Power And Accountability In New Democracies 29 (Marc F. Plattner, Andreas Schedler, \& Larry Diamond eds., 1999). 
general, an electoral commission, a human rights watchdog, an anti-corruption ombudsoffice, a chief public prosecutor, and so on. ${ }^{17}$ These institutions are variously constituted. Some of them are themselves elected, primarily the legislature, and are therefore most likely to be controlled or influenced by the political executive (in parliamentary systems). Usually, it is only the political opposition within the legislature that performs any checking function. ${ }^{18}$ Other institutions, such as the judiciary and other high constitutional offices are constituted through appointments. The appointment mechanism, especially the balance between the respective roles of the political executive and the political opposition in appointments, along with their functional autonomy, is key to the independence of these appointed institutions. Finally, some of these institutions, especially the lower-ranked offices in the bureaucracy and the judiciary, are selected - often through competitive exams.

The political opposition and independent, unelected, state institutions are best able to keep the ruling party and the political executive in check so long as they remain independent and powerful enough to do their job. This ability also makes them extremely attractive targets for executive subordination or party capture.

The third dimension of executive accountability is discursive: to continue with the spatial metaphor, we could call this diagonal accountability. ${ }^{19}$ This is the accountability of the executive (along with other state institutions) to justify its actions in a public discourse with what is called "civil society." Particular civil society institutions, which play a key role in ensuring this discursive accountability, include the media, universities, campaign groups, Non-Governmental Organizations (NGOs), trade unions, religious organizations, and charities.

A pressure on the discursive axis often takes the form of a direct violation of the liberal guarantees of free speech and association (including press freedom

17 On the fourth branch, see Bruce Ackerman, The New Separation of Powers, 113 HARV. L. REv. 633 (2000); Charles Fombad, The Diffusion of South-African Style Institutions? A Study in Comparative Constitutionalism, in Constitutional TRIUMPhS, Constitutional DisAPPOINTMENTS: A CRITICAL ASSESSMENT OF THE 1996 SOUTH AFRICAN CONSTITUTION'S LOCAL AND INTERNATIONAL InFLUENCE 359 (Rosalind Dixon \& Theunis Roux eds., 2018); A.J. Brown, The Integrity Branch: A 'System', an 'Industry', or a Sensible Emerging Fourth Arm of Government?, in MODERN ADMINISTRATIVE LAW IN Australia: CONCEPTS AND CONTEXT 301 (Matthew Groves ed., 2014); Richard Albert \& Michael Pal, The Democratic Resilience of the Canadian Constitution, in CONSTITUTIONAL DEMOCRACY IN CRISIS? 8 (Mark A. Graber, Sanford Levinson, \& Mark Tushnet eds., 2018).

18 This is especially true of India, where individual representatives risk losing their seats if they defy a party whip: see generally INDIA CONST. sch 10.

19 A J Brown calls it the "social dimension." See A J Brown, The Fourth, InTEGRITY BRANCH of GOVERNMENT: RESOLVING A CONTESTED IDEA 11 (July 24, 2018) (transcript on file with author). 
and academic freedom). The goal is often to silence or buy-out criticism and encourage praise for the executive and/or the ruling political party. ${ }^{20}$ The most extreme method of securing this is by shutting down civil society organizations seen as hostile to the ruling party or capturing them through a take over by party loyalists. Frequently, lower level threats, violence, and ill-motivated regulation also suffice. These pressures undermine not only liberty but also democracy because electoral accountability needs discursive accountability to operate effectively. Citizens cannot exercise their function of electorally holding governments to account unless they are properly informed by discursive civil society institutions.

\section{Attacks on Electoral Accountability}

Since it came to power in 2014, the BJP has tried to give itself a partisan advantage in future electoral contests by seeking to change the rules of the game. At least some of these efforts succeeded in the first Modi term, while the others are being vigorously pursued in the second term that began in 2019. At a macro level, this is especially apparent in the nose-diving V-Dem indices concerning campaign finance transparency and the Election Commission's autonomy. ${ }^{21}$

\section{A Demographic Change}

The BJP has a long-standing policy of seeking demographic change by increasing the proportion of Hindus in relation to Muslims. While its main motivation is ideological, such demographic change is likely to benefit the party electorally: for, although not all Hindus vote for the BJP, very few Muslims do, given that the party's main political plank is unrelenting hostility toward Muslims. The Rashtriya Swayamsevak Sangh ("RSS”), BJP's ideological mentor, has long advised Hindu couples to produce more children. ${ }^{22}$ Despite constitutional

20 For a successful use of a buying-out strategy in Hungary, see Patrick Kingsley \& Benjamin Novak, The Website That Shows How a Free Press Can Die, N.Y. Times (Nov. 24, 2018), https://www.nytimes. com/2018/11/24/world/europe/hungary-viktor-orban-media.html.

21 Only the former is discussed in this section. Issues concerning electoral administration are dealt with in a later section on horizontal mechanisms.

22 Mohammad Ali, Produce More Children, RSS Tells Hindu Couples, Hindu (Aug. 22, 2016), https://www.thehindu.com/news/national/other-states/Produce-more-children-RSS-tells-Hinducouples/article14582028.ece; on the RSS generally, see WALTER K. ANDERSEN \& SHRIDHAR D. DAMLE, THE RSS: A VIEW TO THE INSIDE (2018). 
guarantees of religious freedom, several BJP-ruled states have passed anticonversion laws over the years, which make it harder for a person to change their religion (in a Hindu-majority country, the target of these laws are clearly minority religions). ${ }^{23}$

Accusing Muslim men romancing Hindu girls of "love jihad," the BJP launched a campaign to encourage Hindu men to marry Muslim women while discouraging Muslim men from marrying Hindu women (based, no doubt, on the patriarchal assumption that a woman adopts her husband's religion upon marriage). ${ }^{24}$ The BJP government tabled an amendment to India's citizenship laws - hitherto based on jus soli principles - that was designed primarily to extend citizenship to nonMuslim undocumented migrants in the state of Assam, while permitting the deportation of millions of Muslims who failed to prove their residence in India before 1971. ${ }^{25}$ A senior BJP leader and a minister in the Assam government bragged publicly that the Bill was designed to make Assam a "fort” for India's “indigenous people" - a code for non-Muslims for a party that has long associated Islam in India with foreign invaders. ${ }^{26}$ The virulent form of exclusive nationalism practiced under the Modi regime would have been bad enough for India's democracy. ${ }^{27}$ Pursuing demographic changes as part of this ideological agenda challenged even minimalist conceptions of democracy. The government was unable to get the Bill enacted in its first term because of stiff opposition in the upper house (Council of States or Rajya Sabha) of the federal Parliament, but succeeded in doing so in the first year of its second term. Even though the actual demographic dividends did not accrue directly to the BJP in the 2019 general elections, it allowed the party to run a sharply polarized anti-Muslim campaign that is likely to have benefitted it electorally.

23 TARIQ AHMAD, State Anti-Conversion Laws in India, L. Libr. CONGRESS (2018), https://www.loc. gov/law/help/anti-conversion-laws/india.php.

24 Hindu Outfit Plans 'beti bachao, bahu lao' Campaign to Counter Love Jihad, HINDUSTAN TIMES (Dec. 1, 2017), https://www.hindustantimes.com/Lucknow/hindu-outfit-plans-betibachao-bahu-lao-campaign-to-counter-love-jihad/story-HVxTzT8Vn8bAYmYNYVZysI.html; see also Shafin Jahan v. Asokan K.M., (2018) 16 SCC 368 (India).

25 Mihika Poddar, The Citizenship (Amendment) Bill, 2016: International Law on Religion-Based Discrimination and Naturalisation Law, 2 IND. L. REv. 108, 108-18 (2018).

26 Citizenship Bill, Assam Accord, ST Status Will Make Assam a Fort for Indigenous People, Says Himanta Biswa Sarma, News18 (Jan. 24, 2019), https://www.news18.com/news/politics/ citizenship-bill-assam-accord-st-status-will-make-assam-a-fort-for-indigenous-people-says-himantabiswa-sarma-2012611.html.

27 Maya Tudor, India's Nationalism in Historical Perspective: The Democratic Dangers of Ascendant Nativism, 1 India PoL. \& POL’y 107 (2018). 


\section{B Campaign Finance}

In 2014, two major national parties - the BJP and the Congress - were held liable for illegally accepting foreign contributions. ${ }^{28}$ In response, the BJP government retrospectively amended the Foreign Contribution (Regulation) Act 2010 to narrow the definition of a foreign company, and thereby remove the illegality. ${ }^{29}$ This was done surreptitiously - not through a standalone Bill amending the 2010 Act, but via clauses slipped into the Finance Act 2016 (which granted retrospective immunity for receiving illegal foreign donations after 2010) ${ }^{30}$ and another amendment through the Finance Act 2018 (which extended the immunity to all donations received since 1976). ${ }^{31}$ The amendments not only legalized foreign funding of political parties, they also created a new funding vehicle called "electoral bonds" that ensured full anonymity of the donor. ${ }^{32}$ Finance Bills have hundreds of clauses containing many big-ticket items which are in the public domain for a very limited period, so the possibility of proper legislative scrutiny is limited. Furthermore, Rajya Sabha cannot veto "Money Bills." ${ }^{33}$ The partisan character of the new electoral bonds - the only legal way in which a party may secure foreign funding - is evident from these figures: in the 2017-18 financial year (the first year during which the scheme operated), the BJP received anonymous donations through electoral bonds amounting to Rupees 210 crores (or Rupees 2.1 billion - amounting to about $20.4 \%$ of the BJP’s total

28 Association of Democratic Reforms v. Union of India \& Others, (2014) 209 DLT 609.

29 Anuj Srivas, Finance Bill Amends FCRA Again to Condone Illegal Donations to BJP, Congress from Foreign Companies, THE WIRE (Feb. 1, 2018), https://thewire.in/business/finance-bill-seeksamend-fcra-condone-illegal-donations-bjp-congress-received-foreign-companies.

30 Finance Act, No. 28 of 2016, INDIA CODE, $\S 236$.

31 Finance Act, No. 13 of 2018, INDIA CoDE, § 220.

32 Gautam Bhatia, The Electoral Bonds Scheme is a Threat to Democracy, Hindustan Times (Mar. 18, 2019), https://www.hindustantimes.com/analysis/the-electoral-bonds-scheme-is-a-threat-to -democracy/story-PpSiDdUjIw5WNBUzDsSzxI.html?fbclid = IwAR3SrL9-N741ftcthrZBQ XQBrHHbtz MsrZ7_C58FlQnbHwBJZzjJGpHO1k; Adil Rashid, Electoral Bonds Have Legalised Crony Capitalism: ExChief Election Commissioner SY Quraishi, OuTLOoK INDIA (Apr. 07, 2019), https://www.outlookindia. com/website/story/india-news-electoral-bonds-have-legalised-crony-capitalism-ex-chief-electioncommissioner-sy-quraishi/328299. See also Gautam Bhatia, An Ineffectual Angel, Hindu (Apr. 29, 2019), https://www.thehindu.com/opinion/lead/an-ineffectual-angel/article26974278.ece; Gautam Bhatia, Judicial Evasion and the Electoral Bonds Case, Indian Constitutional LaW AND PHILOSOPHY (Apr. 13, 2019), https://indconlawphil.wordpress.com/2019/04/13/judicial-evasion-and-the-electoral-bondscase/.

33 See generally Suhrith Parthasarathy, Trickeries of the Money Bill, Hindu (Apr. 11, 2019), https://www.thehindu.com/opinion/lead/trickeries-of-the-money-bill/article26799226.ece. 
declared earnings), the Congress received Rupees five crores (or Rupees 50 million), and the regional parties received nothing. ${ }^{34}$ In other words, the BJP garnered $97.7 \%$ of funds that were legitimized by surreptitious changes to campaign finance laws! This resulted in the costliest Lok Sabha (lower chamber of Indian Parliament or "House of the People") elections in history, with the BJP accounting for an estimated $45 \%$ of the total expenditure. ${ }^{35}$ While the precise role of this financial advantage in the electoral outcome is hard to pin down, the sheer scale of it makes it difficult to dismiss it as irrelevant to the party's spectacular victory.

\section{Electoral Schedule}

One of the major changes in the Indian electoral system that Prime Minister Modi personally advocated for time and again during his tenure was to hold simultaneous elections for the lower chamber of Indian Parliament and state-level legislative assemblies. Each of these houses has a five-year term. The national and state-level elections were automatically synchronized until $1967 .{ }^{36}$ Since then, elections have taken place in a staggered manner because of the early dissolution of some legislatures. Today, at least one election takes place each year. ${ }^{37}$ Those in favour of a move to a "one-country-one-poll" system argue that back-to-back electoral campaigns cause a distraction from effective governance. ${ }^{38}$ They further argue that making elections a once-in-five-years affair will reduce the costs of conducting and contesting elections. ${ }^{39}$ Offering such managerial justifications

34 Association for Democratic Reforms, ANALysis of SOURCES of Funding of National Parties: FY 2017-18 (2019) 5, https://adrindia.org/download/file/fid/6364.

35 At an Estimated Rs. 60,000 Crore, Lok Sabha Elections Costliest Ever; BJP Spent 45\% of It, Shows Study, News18 (June 4, 2019), https://www.news18.com/news/politics/with-about-rs-100-crspent-in-each-ls-constituency-we-just-witnessed-the-most-expensive-election-ever-2171789.html? ref=hp_top_pos_7.

36 In some cases, the Central Government dismissed the State Governments using its power of imposing "President's Rule" under Article 356. See LAW Commission of India, Draft RePoRt: Simultaneous ElECtions 2-3 (Aug. 30, 2018), http://www.lawcommissionofindia.nic.in/reports/ Simultaneous_Elections.pdf.

37 Id. at 3.

38 Liz Mathew, Simultaneous Elections for Lok Sabha and Assembly: How Idea Came, What Implementation Will Mean, INDIAN EXPRESS (Jan. 31, 2018), https://indianexpress.com/article/ explained/holding-lok-sabha-and-assembly-polls-together-how-idea-came-what-implementationwill-mean-5045403/.

39 Id. 
(like efficiency and rationalization) for a reform that would deliver partisan bonus was a key characteristic of this government's rhetoric.

Other than the political opposition, the only state institution that resisted the move in public debates was the outgoing Election Commissioner of India. ${ }^{40}$ Disagreeing with the efficiency rationale for simultaneous polls, OP Rawat claimed that, given the logistical difficulties of holding simultaneous polls in a country of India's size, "instead of savings, there may be losses and the costs could get higher." 41 The proposal was shelved in the face of the opposition, but has been revived by the second Modi administration. Furthermore, very serious allegations were made about the schedule of the 2019 general elections campaign, which, critics pointed out, was designed to benefit the BJP. ${ }^{42}$

A system of simultaneous polls every five years across India would lead to executive aggrandizement because is likely to take away the legislature's power to dismiss an administration that no longer enjoys its confidence (at least in cases where there is no alternative administration that can command its confidence either). BJP President Amit Shah did not even disguise the fact that the move was designed to secure fixed tenures for the political executive in his letter to the Law Commission recommending it. ${ }^{43} \mathrm{~A}$ key tenet of parliamentary democracy is the legislature's and the political executive's ability to fire one another. Essentially, a simultaneous polls system would take away the legislature's power to fire the political executive, thereby shifting the regime toward the BJP's long sought-after ideological goal of a presidential system - or as close as you can get to it while still pretending to be abiding by parliamentary democracy. Since parliamentary democracy is part of the unamendable basic structure of India's Constitution, an informal constitutional change is being attempted. ${ }^{44}$

40 Chief Election Commissioner on Holding Simultaneous Polls: No Chance at All, INDIAN EXPRESS (Aug. 23, 2018), https://indianexpress.com/article/india/no-chance-at-all-chief-election-commis sioner-o-p-rawat-on-holding-simultaneous-polls-5321447/.

41 Express News Service, OP Rawat: 'Note Ban Had Absolutely No Impact on Black Money. During Polls We Seized a Record Amount', INDIAN EXPRESS (Dec. 2, 2018), https://indianexpress.com/ article/india/op-rawat-cec-note-ban-black-money-polls-assembly-elections-mizoram-5474369/.

42 Ruhi Tewari, Why 2019 Lok Sabha Election Schedule Could Advantage BJP, THE PRINT (Mar. 11, 2019), https://theprint.in/politics/why-2019-lok-sabha-election-schedule-could-mean-advantage-bjp/204210/. 43 Opposition to Simultaneous Polls Is 'Politically Motivated': Amit Shah to Law Commission, THE WIRE (Aug. 14, 2018), https://thewire.in/politics/amit-shah-law-commission-bjp-simultaneouselections.

44 See generally Oran Doyle, Informal Constitutional Change, 65 BufF. L. REv. 1021 (2017). 
Simultaneous polls are also likely to give electoral advantage to the BJP, at least in the short term, thereby reducing the distance between the ruling party and the state. When multiple elections take place simultaneously, big-ticket elections (usually the federal elections) tend to influence down-ballot races at the state level - even if, technically, a voter is free to choose candidates from different parties in the two races. ${ }^{45}$ Given the party system in India, this is likely to benefit national parties at the cost of state-based regional parties. ${ }^{46}$ Furthermore, fully aware of the populist appeal of Prime Minister Modi and the absence of a similarly populist leader in its main rival - the Congress party - a nationwide simultaneous poll in the prevailing political climate could have significantly cemented the BJP's electoral advantage across the country.

The last two changes - the proposal for simultaneous elections and the changes to foreign political donations laws - were designed to target smaller, regional parties which often force the national parties into coalition governments and are a key check on the political executive. In state government, regional parties tend to act more independently of the will of the federal government and are therefore a constant source of irritation to the national parties. The BJP government is therefore trying to nudge India's electoral system toward a two-party system by stifling the space occupied by the smaller parties. Combined with its efforts to decimate the national political rival, the Congress Party, and to accrue electoral advantages by disenfranchising Muslims, its aspiration is to achieve an effectively one-party state.

\section{Erosion of Institutional Accountability I: Containing the Opposition}

Not only did the BJP government seek to undermine electoral accountability to the citizens, it also systematically assaulted institutions that seek horizontal

45 Jagdeep S. Chhokar, Simultaneous Elections: Striking at the Roots of Parliamentary Democracy, 22 (Hindu Centre for Politic and Public Policy, Issue Brief No. 8, 2018), https://www.thehinducentre. com/publications/article23669303.ece/BINARY/Issue\%20Brief\%20No.8.pdf; Ghazanfar Abbas, A Poll Wind: How General Elections Influence Simultaneously Held State Elections in India, NEws18 (Mar. 11, 2019), https://www.news18.com/news/politics/a-poll-wind-how-general-electionsinfluence-simultaneously-held-state-elections-in-india-2062149.html.

46 Suhas Palshikar, Polls Apart, INDIAN EXPRESS (Nov. 24, 2017), https://indianexpress.com/article/ opinion/columns/election-commission-simultaneous-elections-in-india-lok-sabha-assemblyelections-4951569/; Vivek Dahejia, Simultaneous Elections Are a Bad Idea, LivEMINT (July 10, 2018), https://www.livemint.com/Opinion/MgitLxJasfNAbKDhnCQgUJ/Simultaneous-elections-are-a-badidea.html. 
accountability from the political executive. ${ }^{47}$ These political institutions provided a voice to the Opposition, and therefore invited frequent "constitutional hardball" tactics from the government. ${ }^{48}$

\section{A Weakening the Political Opposition: Non-appointment of the Leader of Opposition}

Levitsky and Ziblatt argue that denying the legitimacy of political opponents by describing them as subversives posing an existential threat is a key feature of authoritarian behaviour. ${ }^{49}$ A BJP General Secretary's accusation of treason against the political opposition when it formed an anti-BJP alliance in Kashmir is typical of the BJP's characterisation of the Congress Party and very much meets Ziblatt and Levitsky's criterion. ${ }^{50}$

In the 2014 general elections, the BJP secured a comfortable majority in Lok Sabha. In India, the Leader of Opposition is (at least textually) not a constitutional office. ${ }^{51}$ According to a 1977 legislation that governs the position, the leader of the largest opposition party and recognized by the Speaker as such is the Leader of Opposition. ${ }^{52}$ However, the BJP-appointed Attorney General opined that there is no law that obliges the Speaker to recognize a Leader of the Opposition if no opposition party's numerical strength is at least equal to the quorum of the House (i. e. one-tenth of its membership, or 55 seats). ${ }^{53}$ The BJP-appointed Lok Sabha Speaker refused to recognize a Leader of Opposition on the ground that the Congress Party

47 Liz Mathew, Country Higher than Any Institution, Don't Weaken Elected, Says Arun Jaitley, InDIAN EXPRESS (Oct. 28, 2018), https://indianexpress.com/article/india/country-higher-than-any-institutiondont-weaken-elected-says-arun-jaitley-5421730/.

48 On “constitutional hardball," see Mark V. Tushnet, Constitutional Hardball, 37 J. MARSHALL L. REV. 523 (2004).

49 Steven Levitsky \& Daniel Ziblatt, How Democracies Die: What History Reveals About OuR FUTURE 23 (2018) See also Grégoire Webber, Loyal Opposition and the Political Constitution, 37 Ox. J. LEG. STUD. 357 (2017).

50 Shoaib Daniyal, The Daily Fix: By Accusing Opposition Parties of Treason, BJP is Subverting Indian Democracy, SCRoLL.In (Nov. 23, 2018), https://scroll.in/article/903159/the-daily-fix-byaccusing-opposition-parties-of-treason-bjp-is-subverting-indian-democracy.

51 See generally Subhash C. Kashyap, Qualifying for Leader of the Opposition, Hindu (June 17, 2019), https://www.thehindu.com/opinion/op-ed/qualifying-for-leader-ofthe-opposition/article27957618.ece.

52 Salary and Allowances of Leaders of Opposition in Parliament Act, No. 33 of 1977, INDIA CoDE, § 2. 53 Mukul Rohatgi, Recognition of Leader of Opposition in Sixteenth Lok Sabha, OFF. ATT’Y GEN. INDIA Iा 5 (July 23, 2014), https://barandbench.com/wp-content/uploads/2016/11/lokpal.pdf; Krishn Kausik, Inside Man: The Convenient Opinions of Attorney General Goolam Vahanvati, CARAVAN MAGAZINE (May 1, 2013), https://caravanmagazine.in/reportage/inside-man. 
had garnered only 44 out of 543 seats. ${ }^{54}$ Although several commentators doubted the legality of this decision, ${ }^{55}$ India's overburdened courts failed to rule on the legality of the Speaker's decision even as the 16th Lok Sabha completed its fiveyear tenure in 2019. ${ }^{56}$

Before 2014, the office of the Leader of Opposition had not been vacant since 1989. ${ }^{57}$ The absence of a designated Leader of Opposition mattered because it denied certain perks of office - like a salary and secretarial staff - to the opposition. Further, since 1989, Parliament had reformed or established several independent fourth branch institutions, whose appointment mechanisms of which require the participation of the Leader of Opposition. ${ }^{58}$ The orchestrated vacancy in this office was used by the government as an excuse to stall certain appointments to these fourth-branch institutions. ${ }^{59}$ The Supreme Court intervened to allow these appointments despite the vacancy in the office, ${ }^{60}$ which gave the government a free hand in such appointments. ${ }^{61}$ The 17th Lok Sabha, elected in 2019, does not have an opposition leader either.

\section{B Undermining Bicameralism: Overriding Rajya Sabha's Veto}

In many parliamentary systems, bicameralism is a serious check on the power of the political executive which normally controls the lower legislative

54 Sunii Prabhu, Declined. Speaker Rejects Congress Claim for Leader of Opposition, NDTV (Aug. 19, 2014), https://www.ndtv.com/india-news/declined-speaker-rejects-congress-claim-for-leader-of-opposition650355.

55 P.D.T. Achary, The LoP Excuse, IndiAn EXPRESS (May 3, 2017), https://indianexpress.com/ article/opinion/columns/the-lop-excuse-4637880/.

56 The Delhi High Court refused to entertain a public interest petition challenging this decision of the Speaker: Imran Ali v. Union of India, (2015) SCC OnLine Del 6707. See generally Tarunabh Khaitan, The Indian Supreme Court's Identity Crisis: A Constitutional Court or a Court of Appeals?, 4 IndiAn L. REV. 1 (2020) (empirically demonstrating the Supreme Court's disproportionate disregard of its constitutional docket).

57 See generally Rohatgi, supra note 53.

58 See, e.g., The Right to Information Act, No. 22 of 2005, §§ 12, 15; The Lokpal and Lokayuktas Act, No. 1 of 2014, §4.

59 Common Cause v. Union of India, (2017) 7 SCC 158.

60 Id.

61 See "Special Invitee” Mallikarjun Kharge Refuses To Attend Lokpal Meet, NDTV (Sep. 19, 2018), https://www.ndtv.com/india-news/special-invitee-mallikarjun-kharge-refuses-to-attend-lokpalmeet-1919092 quoting Senior Congress leader Mallikarjun Kharge stating that "[a]n invitation as a special invitee without the right of participation, recording of opinion and voting in the procedure is an eyewash ...." 
chamber. ${ }^{62}$ Generally, both houses of the bicameral Parliament must approve a bill to enact it into law. However, in India, certain bills regulating financial matters enlisted under Article 110 of the Constitution can be enacted as "money bills." Once a bill is certified as a money bill by the Speaker of the lower house, the bill does not require the assent of the upper house to be enacted as law. ${ }^{63}$ In order to circumvent scrutiny by Rajya Sabha, where the BJP did not enjoy majority, a partisan Lok Sabha Speaker characterized the Aadhaar Bill 2016 - validating the national biometric identity program (Aadhaar) - as a money bill. ${ }^{64}$ The provisions of the Bill traversed far beyond the grounds for which the money bill process is normally allowed. ${ }^{65}$ However, the Supreme Court, in a split verdict, upheld the constitutionality of the process. ${ }^{66}$ The dissenting judge went on to call the usage of the money bill route to pass the Aadhaar Act a "fraud on the Constitution." 67

While the Aadhaar Act attracted the most attention, the BJP government used the money bill route with unprecedented frequency, sidestepping the scrutiny by the upper house on some of the most controversial issues. ${ }^{68}$ As already noted, two of these usages were to amend campaign finance laws to retrospectively validate foreign donations to the BJP that had already been declared illegal by the Delhi High Court. The Finance Act 2017 also amended the Representation of the People Act 1951 and the Reserve Bank of India (RBI) Act 1934 to permit unlimited and anonymous corporate donations to political parties through the newly issued electoral bonds. ${ }^{69}$ With the Supreme Court's endorsement of the Speaker's

62 See generally Jeremy Waldron, Bicameralism and the Separation of Powers, 65 CURRENT LEGAL PROBS. 31, 43-51 (2012) (discussing the importance of bicameralism in ensuring executive and judicial independence in Westminster-style governments).

63 IndIA ConST. art. 110; see, e.g., Pratik Datta, Shefali Malhotra \& Shivangi Tyagi, Judicial Review and Money Bills, 10 NUJS L. REV. 75 (2017).

64 Rahul Narayan \& Apar Gupta, The Money Bill Cloud Persists Over the Aadhaar Act, LiveLAW (Oct. 13, 2018), https://www.livelaw.in/the-money-bill-cloud-persists-over-the-aadhaar-act/.

65 Suhrith Parthasarathy, Aadhaar Act as a Money Bill: It Can Lead to a Great Deal of Public Harm, HINDUSTAN TIMES (Sept. 28, 2018), https://www.hindustantimes.com/columns/aadhaar-act-asmoney-bill-it-can-lead-to-a-great-deal-of-public-harm/story-Xu3TtHMSXyrrydO4VcBZgM.html.

66 Justice K.S. Puttaswamy v. Union of India, (2019) 1 SCC 1, [368], (Dipak Misra C.J., Sikri and Khanwillkar, JJ).

67 Id. at [1143] (Chandrachud J).

68 Devyani Chhetri, As Justice Chandrachud Calls Aadhaar Law 'Unconstitutional', Government Increases Use of Controversial Short Cut, BlOOMBERG QUINT (Oct. 3, 2018) https://www.bloom bergquint.com/law-and-policy/as-justice-chandrachud-calls-aadhaar-law-unconstitutionalgovernment-increases-use-of-controversial-short-cut.

69 Representation of the People Act, No. 43 of 1951, §§ 29C, 31; Reserve Bank of India Act, No. 2 of 1934, INDIA CoDE, §13-A; Income Tax Act, No. 43 of 1961, INDIA CoDE, as respectively amended by the Finance Act, No. 14 of 1971, INDIA CoDE, $\S \S 137,135,11$. 
extremely expansive understanding of a money bill, the upper house - often the sole repository of opposition power - was politically enervated.

\section{Unfair Legislative Process: Ignoring the Opposition}

In 2018, in order to avoid a parliamentary debate on crucial financial issues, the government passed the Finance Bill and the Appropriation Bill under an extraordinary parliamentary procedure known as the "guillotine," despite several suggested amendments and strong protest by the Opposition. ${ }^{70}$ This procedure allows the Speaker of the House to put a bill to vote without any discussion. ${ }^{71}$ The use of this procedure was especially disingenuous given that there were still three weeks left in the session of the House, so time was not of the essence. ${ }^{72}$ In 2019 , with elections due within a couple of months, a lame-duck government used the interim budget procedure to present a full, populist, budget - the annual budget from for a government with a five-year term. Yashwant Sinha, the finance minister of India in a former BJP government, described it as a "mockery of the Constitution."73

In 2018, when several opposition parties came together to move a no-confidence motion against the government, the Speaker delayed the motion for over a month. ${ }^{74}$ Such a delay on the part of the Speaker in accepting the no-confidence motion was unprecedented. Even though the government had the numbers, no-confidence motions serve an important function in seeking political accountability from the government, and therefore typically receive priority from the Speaker of the day. ${ }^{75}$ While the government comfortably won the no-confidence motion when it was

70 Meghnad S, How to Get Away with Murder: Parliament Edition, NEwsLAundRY (Mar. 14, 2018), https://www.newslaundry.com/2018/03/14/finance-bill-2018-appropriation-bill-parliamentspeaker-fm-arun-jaitley.

71 Special Correspondent, Guillotine on Budget Debate, The Telegraph (Mar. 15, 2018), https://www.telegraphindia.com/india/guillotine-on-budget-debate/cid/1338698.

72 E.T. Bureau, Lok Sabha Passes Budget Without Debate; Both Houses Adjourn Amid Din, THE ECONOMic Times (Mar. 15, 2018), https://economictimes.indiatimes.com/news/politics-and-nation/ finance-bill-to-be-taken-up-in-lok-sabha-at-noon/articleshow/63296956.cms.

73 Yashwant Sinha, With Sixth Budget, Government Has Made a Mockery of Constitution, NDTV (Feb. 2, 2019), https://www.ndtv.com/opinion/with-sixth-budget-government-has-made-a-mockery-ofconstitution-1987434.

74 P.D.T. Achary, The Speaker is Wrong to Not Allow No-Confidence Move to be Tabled, THE WIRE (Mar. 26, 2018), https://thewire.in/government/the-speaker-is-wrong-to-not-allow-no-confidencemove-to-be-tabled.

75 M.R. Madhavan, Confidence in the House, Hindu (Apr. 5, 2018), https://www.thehindu.com/ opinion/op-ed/confidence-in-the-house/article23437310.ece. 
eventually brought up, it managed to avoid a publicly televised parliamentary debate on its performance before a crucial state election in Karnataka. ${ }^{76}$

\section{Attacking Federalism: Abuse of the Offices of Governors and Lieutenant Governors ${ }^{77}$}

By no means the first government to do so, the BJP government continued India's long and unfortunate tradition of abusing a constitutional design flaw the centrally appointed office of a governor in every state in the country, who holds office at the president's pleasure (manifested on the advice of the prime minister). ${ }^{78}$ Although a largely ceremonial head, the governor performs certain key political functions. Most importantly, in case of a hung assembly where no party has a clear majority, the governor appoints the leader of the party she believes is most likely to secure the confidence of the House as Chief Minister. The advantage of political office is so immense that even the few days within which a new Chief Minister has to prove her majority in the assembly are usually sufficient to coax, cajole, buy, or coerce the support of smaller parties, independents, and even factions within the main political rivals. Like its predecessors, the BJP government dismissed nine governors appointed by the previous government soon after assuming power in 2014. ${ }^{79}$ BJP-appointed governors have typically obliged their political masters.

In 2016, obliging governors of the states of Uttarakhand and Arunachal Pradesh - which were ruled by parties that were in opposition at the center - reported that the constitutional machinery in these states had broken down, leading to the federal government dismissing the state governments and assuming direct rule. ${ }^{80}$

76 Hartosh Singh Bal, India's Embattled Democracy, N.Y. TimES (May 30, 2018), https://www. nytimes.com/2018/05/30/opinion/india-democracy.html.

77 On the Modi government's impact on political federalism, see generally Chanchal Kumar Sharma \& Wilfried Swenden, Modi-fying Indian Federalism? Center-State Relations under Modi's Tenure as Prime Minister, 1 IND. PoL. \& PoL'Y 51 (2018). For a possible impact of the Modi government's tax policy on fiscal federalism, see Suhrith Parthasarathy, Taxing Times for the States, THE HINDU (July 25, 2017), https://www.thehindu.com/opinion/lead/taxing-times-for-the-states/ article19346974.ece.

78 BP Singhal v. Union of India, (2010) 6 SCC 331.

79 Sharma \& Swenden, supra note 77, at 59.

80 Rahul Tripathi, President's Rule Imposed in Uttarakhand After Governor's Report, ECON. TIMES (Mar. 28, 2016), https://economictimes.indiatimes.com/news/politics-and-nation/presidents-rule-imposedin-uttarakhand-after-governors-report/articleshow/51570914.cms; Nabam Tuki Blames RSS and BJP For Dismissal of His Government in Arunachal, NDTV (Feb. 20, 2016), https://www.ndtv.com/indianews/nabam-tuki-blames-rss-and-bjp-for-dismissal-of-his-government-in-arunachal-1279499. 
In both cases, the Supreme Court intervened to restore the dismissed governments. ${ }^{81}$

In 2017, when the Goa assembly returned with a hung verdict, the governor invited the alliance led by the BJP, which had superior numbers to the singlelargest party (the Congress). However, in 2018, the Karnataka governor decided to invite the single-largest party lacking a majority (the BJP) rather than a coalition with a clear majority (that included the Congress) to form a government. ${ }^{82}$ It is clear that the decisions were motivated not by the likelihood of confidence but by partisan considerations. The Supreme Court made an uncharacteristically timely intervention by ordering an immediate floor-test in Karnataka, ${ }^{83}$ which the BJP failed. ${ }^{84}$ Consequently, its nominee stepped down as the Chief Minister, and the coalition formed the government. ${ }^{85}$

In November 2018, when the non-BJP parties formed a coalition with a clear majority to form a government in the state of Jammu and Kashmir, the Governor simply dissolved the House and called for fresh elections, characterizing the alliance as "unholy." 86 The governor later hinted that by dissolving the assembly, he chose the lesser of the two evils and resisted pressure from the federal government to install a minority BJP government in the state instead. ${ }^{87}$

While the occasion for abusing the governors' offices arises only rarely, BJPappointed lieutenant governors (LGs) - with a wider range of powers - have been

81 Utkarsh Anand, Lessons from Uttarakhand and Arunachal: What Court Orders on Central Rule Say, INDIAN EXPRESS (July 15, 2016), https://indianexpress.com/article/explained/arunachalpradesh-verdict-nabam-tuki-harish-rawat-uttarakhand-president-rule-supreme-court-modigovernment-2914435/.

82 Krishnadas Rajagopal, Legal Experts Divided Over Karnataka Governor's Invitation to Yeddyurappa to Form Government, Hindu (May 16, 2018), https://www.thehindu.com/elections/ karnataka-2018/let-karnataka-governor-explore-all-alternatives/article23905846.ece.

83 Bhadra Sinha \& Vikram Gopal, Supreme Court Orders BJP's Yedurappa to Face Floor Test in 24 h, Hindustan TimEs (May 18, 2018), https://www.hindustantimes.com/india-news/supreme-courtasks-yeddyurappa-to-prove-majority-tomorrow-does-not-get-into-legality-of-governor-s-decision/ story-St4IAbhb1ZwusGnHuzOtDP.html.

84 Karnataka Governor Invites Congress-JDS Alliance to Form Government, HINDUSTAN TIMES (May 19, 2018) https://www.hindustantimes.com/india-news/karnataka-governor-invites-congressjds-alliance-to-form-government-15-days-to-prove-majority/story-yh89AgZdEqjex2SjmgT0ZP. html.

85 Id.

86 Mir Ehsan, Jammu and Kashmir's Political Thriller Ends In Anti-Climax, Assembly Dissolved, HinduSTAN Times (Nov. 22, 2018), https://www.hindustantimes.com/india-news/j-k-s-politicalthriller-ends-in-anti-climax-house-dissolved/story-Cp8VZPABYgZtrEqAScAsoI.html.

87 Nazir Masoodi \& Deepshikha Ghosh, J\&K Governor Talks "Threat of Transfer" After Controversy Over Remarks, NDTV (Nov. 28, 2018), https://www.ndtv.com/india-news/jammu-and-kashmirgovernor-satya-pal-malik-talks-threat-of-transfer-after-controversy-over-remarks-1954488. 
unrelenting in the abuse of their office in the union territories of Delhi and Puducherry. In 2015, a new party - the Aam Aadmi Party - arising out of an anticorruption movement, formed government in National Capital Territory (NCT) of Delhi. ${ }^{88}$ Soon after Delhi election, the federal government, acting through the LG, not only made key appointments contrary to the wishes of the Delhi cabinet, but also obstructed major policies and legislative initiatives of the elected government of Delhi. ${ }^{89}$ In part, these controversies are owed to Delhi's peculiar status in the Indian constitutional scheme. While it does have an elected parliamentary government, the powers of Delhi's elected executive are somewhat less than those of fully-fledged states. ${ }^{90}$

When the matter concerning the extent of the LG's powers reached the Supreme Court, the Court interpreted the LG's powers narrowly, ${ }^{91}$ holding that he cannot override a decision of the elected government of Delhi unless an "executive act of the government of the NCT is likely to impede or prejudice the exercise of the executive power of the Union government." 92 While the judicial caveat left enough ambiguity for the LG to continue with some meddling, ${ }^{93}$ even this limited relief came after the elected Delhi government had already completed almost three and a half of its five years in office. While LGs, like governors, are political appointees of the federal government, this level of interference by an LG is

88 Election Commission of India, Statistical Report on General Election, 2015 to the Legislative Assembly of NCT of Delhi, https://eci.gov.in/files/file/3878-delhi-2015/.

89 Rajgopal Saikumar, More Constitutional Than Political, Hindu (May 23, 2015), https://www.the hindu.com/opinion/lead/more-constitutional-than-political/article7236281.ece; Delhi LG Anil Baijal Blocking Scheme for Education Loan to Poor, Alleges Manish Sisodia, Ind. Express (Sept. 22, 2017), https://indianexpress.com/article/india/delhi-lg-anil-baijal-blocking-scheme-for-education-loanto-poor-alleges-manish-sisodia-4856617/.

90 InDIA Const. art. 239AA(4) amended by The Constitution (69th Amendment) Act, 1991 ("[I]n the case of difference of opinion between the Lieutenant Governor and his Ministers on any matter, the Lieutenant Governor shall refer it to the President for decision and act according to the decision given thereon by the President").

91 State (NCT of Delhi) v. Union of India (2018) 8 SCC 501, [284.18] (Misra J).

92 Id at [474] (Chandrachud J).

93 Harish V Nair, Delhi CM vs L-G: Round 2 Begins in SC Tomorrow, IndiA TodAY (July 16, 2018) https://www.indiatoday.in/mail-today/story/delhi-cm-vs-l-g-round-2-begins-in-sc-tomorrow1286575-2018-07-16; Delhi Govt Vs LG: “Govt Paralysed, Can't Appoint/Transfer Officers, Submits Delhi Govt. but SC Defers Hearing of Pending Issues, LiveLAw (Jul 26, 2018), https://www.livelaw.in/ kejriwal-vs-lg-govt-paralysed-cant-appoint-transfer-officers-submits-delhi-govt-but-sc-defershearing-of-pending-issues-to-july-26/. 
unprecedented. ${ }^{94}$ Furthermore, in Puducherry, another territory with a peculiar constitutional status comparable to Delhi, its LG - also appointed by the federal government - continued to interfere in policy decisions and day-to-day administration by the elected government until the intervention of the Madras High Court. $^{95}$

Conventions surrounding center-state relations have also been breached. One opposition-ruled state that has earned the particular ire of the federal government is Bengal, whose chief minister has been an outspoken critic of Prime Minister Modi. In 2016, the government deployed the army throughout the state without the prior consent of the state government, and without any obvious threat to national security. ${ }^{96}$ In 2019, the center-controlled Central Bureau of Investigation (CBI) moved to arrest the chief of the state police (who function under the supervision of the state government), again without the consent of the state government. ${ }^{97}$

94 Aniruddha Ghosal, Delhi Deadlock: How it Was Under Sheila Dikshit and What Changed After Arvind Kejriwal Came to Power, NEws18 (Feb. 14, 2019), https://www.news18.com/news/india/ delhi-deadlock-how-it-was-under-sheila-dikshit-and-what-changed-after-arvind-kejriwal-cameto-power-2035781.html.

95 K. Lakshminarayanan v. Union of India, W.P. 28890 of 2017 (2019), http://164.100.79.153/ judis/chennai/index.php/casestatus/viewpdf/462147. See also Megha Kaveri, Win for Puducherry CM, Madras HC Rules LG Cannot Interfere in Govt's Daily Affairs, News MinuTE (Apr. 30, 2019), https://www.thenewsminute.com/article/win-puducherry-cm-madras-hc-rules-lg-cannotinterfere-govt-s-daily-affairs-100943; CM vs LG: Puducherry Power Struggle May Now Become a Legal Tussle, News Minute (July 2, 2017), https://www.thenewsminute.com/article/cm-vs-lgpuducherry-power-struggle-may-now-become-legal-tussle-64536; Rajesh Nair, SC Verdict Relevant to Puducherry Too, Chief Minister Narayanasamy, Hindu (July 4, 2018), https://www.thehindu. com/news/cities/Puducherry/sc-ruling-on-l-gs-powers-applies-to-puducherry-too-saysnarayanasamy/article24330112.ece; Puducherry Power Tussle: Here's L-G Kiran Bedi's Counter to CM Narayanasamy's Contempt Threat, FinANCIAL EXPRESS (July 5, 2018), https://www.financial express.com/india-news/puducherry-power-tussle-heres-l-g-kiran-bedis-counter-to-cm-narayanasamyscontempt-threat/1232354/.

96 Aniruddha Ghosal, Mamata Banerjee Compares Situation in Bengal to 'Military Coup', InDIAN EXPRESS (Dec. 2, 2016), https://indianexpress.com/article/india/mamata-banerjee-army-deploymentnh-2-in-west-bengal-military-coup-4405871/.

97 Proem Shankar Jha, We Are Witnessing the Death of the CBI. Will Indian Democracy Follow?, WIRE (Feb. 06, 2019), https://thewire.in/politics/cbi-mamata-banerjee-narendra-modi; Aniruddha Ghosal, 'There was a Plan': How Mamata's Offencive Escalated to Catch Modi Govt Off Guard, NEws18 (Feb. 04, 2019), https://www.news18.com/news/india/there-was-a-plan-how-mamatasoffencive-escalated-to-catch-modi-govt-off-guard-2024455.html. 


\section{E Side-lining the Cabinet and Rivals within the Party}

The leadership tried to side-line not only the political opposition, but also allies and cabinet ministers from the BJP. Unlike a presidential system of government, in a parliamentary system the prime minister is technically the first among equals. No doubt, the actual power and influence of a prime minister depends on her personality, charisma, and the support she enjoys within the parliamentary party. Even so, members of the cabinet have usually exercised some restraint on her powers. Given the opaqueness around internal cabinet politics and the principle of collective responsibility, it is usually hard to know for certain whether and to what extent the cabinet has acted as a check on a prime minister. But the resignation letter of a minister from Modi's cabinet does offer some clue:

You have systemically dismantled the functioning of the cabinet of the government that is mandated in our constitution. The Union Cabinet has been reduced to a mere rubber stamp, simply endorsing your decision without any deliberation. Ministers and officers posted in ministries have become figureheads as virtually all decisions are taken by you, your office and the BJP President. (Which is anti-constitutional)

"It is unfortunate that priority of the government is not to work for the poor and the oppressed but to fix political opponents by hook or by crook. Investigating agencies are being remote controlled by your office and the BJP President with the sole purpose of harassing leaders with contrarian views. Constitutional offices are being undermined and virtually every institution in the government has been subjected to political appropriation. ${ }^{98}$,

Of course, words of a disgruntled ally, spoken when the relationship is breaking down, need to be taken with a pinch of salt. But complaints of autocratic behaviour have not just come from disgruntled allies, but from within the BJP itself. Soon after assuming power, the BJP President Amit Shah effectively purged the party of its veteran leaders by consigning them to a powerless advisory council (Margdarshak Mandal). ${ }^{99}$ These forcibly-retired party insiders

98 Upendra Kushwaha's Strongly Worded Resignation Letter: Full text, DNA INDIA (Dec. 10, 2018), https://www.dnaindia.com/india/report-upendra-kushwaha-s-strongly-worded-resignationletter-full-text-2694312 (parenthesis in the original).

99 Ashutosh Bhardwaj \& Amitabh Sinha, Margdarshak Mandal: Resentment Boils Over, Was Simmering for Long, INDIAN EXPRESS (Nov. 11, 2015), https://indianexpress.com/article/India/indianews-india/margdarshak-mandal-resentment-boils-over-was-simmering-for-long/; Dhirendra $\mathrm{K}$ Jha, BJP Meet: Party Agog with Talk that Veteran Will Propose that Margdarshak Mandal Be Scrapped, SCROLL.IN (Sep. 8, 2016), https://scroll.in/article/815940/bjp-meet-party-veteran-saidto-be-set-to-propose-that-the-margdarshak-mandal-be-scrapped. 
felt compelled to issue a public statement complaining that "the party is forced to kow-tow to a handful and ... its consensual character has been destroyed."100

\section{Erosion of Institutional Accountability II: Capturing or Undermining the Judiciary \& Fourth Branch Institutions}

The Modi government undermined mechanisms that allow appointed institutions to seek accountability from the executive. These institutions are constituted not by elections but by various appointments processes, and typically include high constitutional offices. The higher judiciary is a key component. So are a variety of fourth branch institutions that do not neatly fit into the traditional tripartite division between the executive, the legislature and the judiciary, and include the RBI, the Auditor General, the anti-corruption watchdog, the Information Commission, the Election Commission, the Human Rights Commissions, various equality commissions and so on. Although often appointed by the executive in India, these fourth branch institutions are usually meant to function independently and typically not required to report to any governmental ministry.

\section{A Interference with Judicial Independence and Appointments}

The Indian Constitution envisages a wide jurisdiction for the Supreme Court. ${ }^{101}$ It is an eccentric court that some commentators have described as "the most powerful

100 Devparna Acharya, After Advani, it's Yashwant Sinha's Turn: What's Going on in BJP Party Ranks is Hardly Unexpected, FIRSTPOST (Feb. 01, 2016), https://www.firstpost.com/politics/afteradvani-its-yashwant-sinhas-turn-whats-going-on-in-bjp-party-ranks-is-hardly-unexpected2606360.html.

101 Arun K. Thiruvengadam, The Crisis in Context, FrontLine (Feb. 16, 2018), https://www. frontline.in/cover-story/the-crisis-in-context/article10055190.ece. The very wide appellate jurisdiction of the Court has, in fact, become an impediment to its ability to satisfactorily perform its constitutional defence function: see generally Tarunabh Khaitan, The Supreme Court as a Constitutional Watchdog, 721 SEMINAR 22 (2019). 
court of the world."102 It has significant influence over other judiciaries in the global South. ${ }^{103}$

It is unsurprising that the power over the appointment of its judges has been a cause of a fraught relationship between the executive and the judiciary for almost the entire life of the Constitution. ${ }^{104}$ Partly in response to Indira Gandhi's quest for a pliant judiciary in the 1970s, the Supreme Court established the "collegium," a body comprising five senior-most judges, in $1993 .{ }^{105}$ On a strained interpretation of the Constitution, the collegium was primarily tasked with appointments to higher judiciary and subsequently came to be regarded as a bulwark for judicial independence. ${ }^{106}$ Although fiercely independent in its appointments process, Supreme Court judges retire at the relatively young age of 65 (for High Court judges, the retirement age is 62). Most of these former judges are appointed to various tribunals and fourth branch institutions upon retirement from the judicial office, which are in turn made by the political executive, allowing it significant systemic influence over the career of a judge.

In 2014, the Modi government, with the support of the Opposition, passed a constitutional amendment to overhaul the process of appointments to the higher judiciary. ${ }^{107}$ The amendment took away judicial primacy in judicial appointments, and gave the executive an upper hand. In 2015, the Supreme Court struck down the amendment on the grounds of erosion of judicial independence, which is part of the basic structure of the Constitution. ${ }^{108}$ While the amendment itself had broad political support, the executive's retaliation after it was struck down has been conspicuous. ${ }^{109}$ The government has since then selectively resisted the elevation

$102 I d$.

103 See generally Arun Thiruvengadam, Global Dialogue Among Courts: Social Rights Jurisprudence of the Supreme Court of India from a Comparative Perspective, in HUMAN RIGHTS, JUSTICE, \& Constitutional Empowerment 264 (C. Raj Kumar \& K. Chockalingam eds., second ed. 2007); A. Thiruvengadam, Revisiting The Role of the Judiciary in Plural Societies (1987): A Quarter-Century Retrospective on Public Interest Litigation in India and the Global South in Comparative Constitutionalism in South Asia ch. 11 (S Khilnani, Sunil Khilnani, Vikram Raghavan, \& Arun K. Thiruvengadam eds. 2012).

$104 \mathrm{Id}$.

105 Supreme Court Advocates-on-Record Association v. Union of India, (1993) 4 SCC 441.

106 Rohit De \& Tarunabh Khaitan, In Defence of Constitutionalism, I-CONNECT: INT’L J. Const. L. BLOG (Jan. 19, 2018), http://www.iconnectblog.com/2018/01/in-defence-of-constitutionalism/.

107 InDIA Const. amended by The Constitution (99th Amendment) Act, 2014.

108 See Supreme Court Advocates-on-Record Association v. Union of India (2016) 5 SCC 1.

109 'Indian Democracy Cannot Be a Tyranny of the Unelected': Arun Jaitley's 'Alternative View' on NJAC Verdict, FIRSTPOST (Oct. 19, 2015), https://www.firstpost.com/politics/indian-democracycannot-be-a-tyranny-of-the-unelected-arun-jaitleys-alternative-view-on-the-njac-verdict2473218.html. 
of nominees who were seen as unfavourable for partisan or ideological reasons. ${ }^{110}$ A petition concerning these delays in judicial appointments was pending before the overburdened Supreme Court at the time of writing this article. ${ }^{111}$ Its appointment of a retired Chief Justice as the governor of a state - a political appointment - was only the second time a Supreme Court judge was thus appointed, and criticized for its implications for judicial independence. ${ }^{112}$

There were some serious allegations against the government for meddling with judicial function behind the scenes. In January 2018, four of the five senior-most judges of the Indian Supreme Court, who constituted its collegium, held an unprecedented joint press conference. They released an open letter to the fifth member of the collegium, the then Chief Justice of India (CJI), and complained that long-standing conventions governing the CJI's role as the "master of roster" were being ignored. ${ }^{113}$ The Indian Supreme Court sits in benches of varying sizes. While ordinarily the composition of different benches and allocation of cases between them is decided through an automated system, the CJI, as the master of roster, retains the residual power to assign benches. ${ }^{114}$ This time, the suggestion was that the CJI may have used his powers to benefit the ruling party and its leaders in certain politically sensitive cases. ${ }^{115}$ In particular, there was high drama around the assignment of a case concerning the alleged murder of a trial court judge who was investigating a murder case that implicated the BJP President Amit Shah. ${ }^{116}$ The irregular assignment of this case to a bench headed by the then-CJI, which decided that there was no need for further investigation into the case, was one of the primary motivations

110 K. Parameshwar, Alok Prasanna Kumar \& Tarunabh Khaitan, Was the Centre Right in Resisting Justice Joseph's Elevation?, HINDU (May 4, 2018), https://www.thehindu.com/opinion/op-ed/wasthe-centre-right-in-resisting-justice-josephs-elevation/article23764213.ece.

111 SC to Hear Plea on Govt Delays Over Appointment of Judges in Higher Judiciary After 8 Weeks, TiMES OF INDIA (Nov. 2, 2018), https://timesofindia.indiatimes.com/india/sc-to-hear-plea-on-govtdelays-over-appointment-of-judges-in-higher-judiciary-after-8-weeks/articleshow/66480494. cms.

112 V. Venkatesan, Justice as Governor, FRONTLINE (Oct. 3, 2014), https://frontline.thehindu.com/ the-nation/justice-as-governor/article6412702.ece.

113 Full Text of the Letter Four Supreme Court Judges Wrote to India's Chief Justice, QUARTZ (Jan. 12, 2018), https://qz.com/1178370/full-text-of-the-letter-four-supreme-courtjudges-write-to-the-chief-justice-of-india/.

114 Asok Pande v. Supreme Court of India, (2018) 5 SCC 341.

115 Saptarshi Ray, India's Top Judges Accuse Chief Justice of Undue Influence in Hearings, TeleGRAPH (Jan. 14, 2018), http://www.telegraph.co.uk/news/2018/01/14/indias-top-judges-accusechief-justice-undue-influence-hearings/.

116 Dushyant Dave, Death of a Judge: There is Much More Than Meets the Eye, BAR \& BENCH (Jan. 19, 2018), https://barandbench.com/judge-loya-death-dushyant-dave/. 
for the press conference by the four other members of the collegium. ${ }^{117}$ One of the four senior judges who held the press-conference publicly confirmed after his retirement that they did indeed believe that the CJI was acting under "external influence" and that bench allocations were tainted by "political bias". ${ }^{118}$ Another wrote in a letter to the CJI that:

We, the judges of the Supreme Court of India, are being accused of ceding our independence and our institutional integrity to the Executive's incremental encroachment. The Executive is always impatient, and brooks no disobedience even of the judiciary if it can. Attempts were always made to treat the Chief Justices as the Departmental Heads in the Secretariat. So much for our "independence and preeminence" as a distinct State organ. ${ }^{119}$

Subsequent to the press conference, given the seriousness of the charges, a few members of the parliamentary opposition filed an impeachment motion against the CJI. ${ }^{120}$ However, India's Vice President - a former president of the BJP - refused to allow the motion to proceed without even ordering a preliminary investigation into the allegations. ${ }^{121}$

While the BJP's hand in the above-mentioned episode is shrouded in mystery, its role in calling for open defiance of a judicial order is very public. In a 2018 decision, the Supreme Court ordered that women should be allowed to worship in a Hindu temple in Southern India, where women of certain ages were previously prohibited from entering. ${ }^{122}$ While the Communist Party government in the state where the temple is located hailed the verdict, BJP President Amit Shah threatened to uproot the state government if it continued to enforce the order by arresting people protesting (and frustrating) the implementation of the Supreme Court's order (by physically blocking access to

117 Loya Case the Tipping Point, Four SC Judges Say Democracy Is in Danger, WIRE (Jan. 12, 2018), https://thewire.in/law/sc-justices-hold-historic-press-conference-triggered-judge-loya-case.

118 We Thought Ex-CJI Dipak Misra Was Under 'External Influences': Kurian Joseph, WIRE (Dec. 03, 2018), https://thewire.in/law/dipak-misra-kurian-joseph-supreme-court.

119 Aditya AK, Bonhomie Between Judiciary and Government Sounds the Death Knell to Democracy; Chelameswar J in letter to CJI, BAR \& BENCH (Mar. 29, 2018), https://barandbench.com/bonhomiebetween-judiciary-and-government-sounds-the-death-knell-to-democracy-chelameswar-j-inletter-to-cji/.

120 Amy Kazmin, India's Opposition Moves to Impeach Supreme Court Chief Justice, FinanCIAL TiMES (Apr. 21, 2018), https://www.ft.com/content/90ca99ba-4486-11e8-803a-295c97e6fd0b.

121 Shri M. Venkaiah Naidu, Order by the Vice President, (Apr. 23, 2018), https://rajyasabha.nic.in/ rsnew/HC_orders_mothion.pdf; Amy Kazmin, Congress Party Motion to Impeach India's Top Judge Rejected, Financial Times (Apr. 24, 2018), https://www.ft.com/content/ffadea5e-46f6-11e8-8ae94b5ddcca99b3.

122 Indian Young Lawyers Association v. The State of Kerala, (2018) SCC OnLine SC 1690. 
the temple by female activists). ${ }^{123}$ The BJP also led protests against its enforcement, ${ }^{124}$ resulting in several violent incidents. ${ }^{125}$

\section{B Disabling or Capturing the Fourth Branch}

Contemporary constitutions subject the executive to the scrutiny not only of the political opposition and the judiciary, but also of various fourth branch institutions that typically include an auditor-general, an electoral commission, a human rights watchdog, an anti-corruption ombudsoffice, a chief public prosecutor and so on. ${ }^{126}$ In India, some of these institutions, like the Election Commission, are created by the Constitution itself. Others like the Human Rights Commission, established by statutes, have a quasi-constitutional status. The Modi government has worked systematically to either cripple these institutions to prevent them from performing their accountability-seeking function (often by simply refusing to fill vacancies) or pack them with party ideologues to ensure their institutional capture. The fact that the political executive has an exclusive (or, at least, dominant) say in appointments to most of these institutions has aided the project of ideological capture of these institutions, which are increasingly being staffed by affiliates of the BJP's parent organization and ideological mentor: the RSS.

\section{Lokpal}

After a long drawn anti-corruption movement, the outgoing government headed by the Congress Party enacted the Lokpal and Lokayuktas Act in 2013. This Act aimed to establish an independent anti-graft ombudsoffice (the Lokpal). Despite the BJP's prominent role (then as an opposition party) in demanding the legislation, and repeated reprimands by the Supreme Court, the Modi

123 Gaurav Mukherjee \& Malavika Prasad, By Threatening Kerala's Government for Enforcing Sabarimala Order, Amit Shah Breached His Oath as MP, SCROLL.IN (Nov. 18, 2018), https://scroll.in/ article/902308/by-threatening-keralas-government-for-enforcing-sabarimala-order-amit-shahbreached-his-oath-as-mp?fbclid=IwAR1fuAjAzfhIomEK8VRzcmZ4tsnpYS40nhQJ8oqetPaUIf_ xNa52UsWVXUU.

124 Shaju Philip, Amit Shah Asks on Sabarimala: Why Issue Orders that Can't be Enforced?, INDIAN EXPRESS (Oct. 28, 2018), https://indianexpress.com/article/india/amit-shah-asks-on-sabarimalawhy-issue-orders-that-cant-be-enforced-5421715/.

125 Kai Schultz, Clashes Blocking Women from Temple in India Bring Over 2,000 Arrests, N.Y. TIMES (Oct. 26, 2018), https://www.nytimes.com/2018/10/26/world/asia/india-hindu-temple-arrests. html.

126 Albert \& Pal, supra note 17. 
government failed to appoint a Lokpal for most of its tenure of five years. ${ }^{127}$ The government took more than four years to even establish a search committee, ${ }^{128}$ based on which an appointment was made in the dying days of the first Modi government. In the absence of an official opposition leader, the Opposition was sought to be represented on the selection committee by a special invitee who could attend but not vote - the invitee understandably turned down the insulting invitation. ${ }^{129}$

\section{Central Bureau of Investigation}

The CBI is the premier investigative agency in the country. ${ }^{130}$ Despite its crucial role, the Bureau does not stand on a firm constitutional ground. ${ }^{131}$ It is a federal body with police powers in a constitutional scheme where such powers ordinarily reside with state governments. ${ }^{132}$ The complicated legal status not only raises questions about the constitutionality of the Bureau, ${ }^{133}$ but also compromises its independence and accountability. ${ }^{134}$ The Director of the CBI - selected by a committee comprising the Prime Minister, the Leader of Opposition and the CJI -

127 Common Cause v. Union of India, (2017) 7 SCC 158; Krishnadas Rajagopal, Govt Stand on Lokpal Appointment is 'Wholly Unsatisfactory,' Says Supreme Court, Hindu (July 24, 2018), https://www.thehindu.com/news/national/govt-stand-on-lokpal-apointment-is-wholly-unsatisfactorysays-supreme-court/article24502495.ece.

128 Bharti Jain, Centre Announces 8-Member Search Committee For Lokpal, TIMES OF INDIA (Sep. 27, 2018), https://timesofindia.indiatimes.com/india/centre-announces-8-member-search-committeefor-lokpal/articleshow/65985596.cms.

129 Mahesh Langa, Justice P.C. Ghose Appointed First Lokpal, Hindu (Mar. 19, 2019), https://www.thehindu.com/news/national/justice-pc-ghose-appointed-first-lokpal/article26582874. ece; Anjali Bhardwaj, How Not to Appoint a Lokpal, WIRE (Mar. 20, 2019), https://thewire.in/ government/how-not-to-appoint-a-lokpal.

130 A.G. Noorani, A Charter for the CBI, Hindu (Aug. 21, 2013), https://www.thehindu.com/ opinion/lead/a-charter-for-the-cbi/article5042518.ece.

131 See generally Mathew Idiculla, CBI Does Not Need to Be Saved from Narendra Modi. It Needs to Be Dismantled, SCROLL.IN (Feb. 13, 2019), https://scroll.in/article/912652/cbi-does-not-need-to-besaved-from-narendra-modi-it-needs-to-be-dismantled.

132 Anil Chowdhry, Independence of CBI: Myth and Reality, REDIFF (May. 15, 2013), http://www.rediff. com/news/column/independence-of-cbi-myth-and-reality/20130515.htm.

133 SC Stays Gauhati High Court Order Declaring CBI Unconstitutional, INDIAN EXPRESS (Feb. 18, 2018), https://indianexpress.com/article/India/india-others/sc-stays-gauhati-high-court-orderdeclaring-cbi-unconstitutional/; See Navendra Kumar v. The Union of India, (2013) SCC OnLine Gau 305 Iा 179 (in which the court declared the establishment of the CBI to be ultra vires of the Indian Constitution).

134 Manish Tewari, Is CBI a Legal Entity?, DECCAN ChronICLE (Oct. 28, 2018), https://deccanchronicle. com/opinion/columnists/281018/is-cbi-a-legal-entity.html. 
enjoys a fixed tenure of two years. ${ }^{135}$ However, there is little independence as the Bureau's administrative control vests with the government.

Allegations of the politicization of the CBI are not new. Previous governments frequently used the CBI to selectively investigate their political adversaries, which led the CJI to describe the body as "a caged parrot speaking in its master's voice."136 Even against the backdrop of this fraught history, the crisis under the Modi government was unprecedented. ${ }^{137}$ The top two officers of the agency made allegations of bribery against each other. ${ }^{138}$ After the Director of the Bureau filed a case against the Deputy Director, the latter complained to the government about the former. ${ }^{139}$ The government reacted to this by sending both top officials on indefinite leave despite the legally-guaranteed fixed tenure of the CBI Director. ${ }^{140}$ The Government's justification was that since the top two officers were at loggerheads, sending the officers on forced leave was essential to conduct an impartial inquiry into the charges levelled against them. ${ }^{141}$ The CBI Director approached the Supreme Court, challenging the government's decision, where he also claimed that the government was exercising its influence to interfere with the CBI's functioning. ${ }^{142}$ Opposition parties alleged that the suspension of the CBI Director was an orchestrated attempt to thwart investigation into recent corruption allegations against the government. ${ }^{143}$ In less than 48 hours after the Supreme Court invalidated his suspension, ${ }^{144}$ the committee empowered to appoint the director

135 Delhi Special Police Establishment Act, No. 25 of 1946, India CodE, § 4B.

136 Ross Colvin \& Satarupa Bhattacharjya, A "Caged Parrot" - Supreme Court Describes CBI, REUTERS (May 10, 2013), https://in.reuters.com/article/cbi-supreme-court-parrot-coal/a-cagedparrot-supreme-court-describes-cbi-idINDEE94901W20130510.

137 Ritu Sarin, A Lower Low, INDIAN EXPRESS (Oct. 26, 2018), https://indianexpress.com/article/ opinion/a-lower-low-5418861/.

138 The Corruption Scandal Marring India's CBI, BBC (Oct 26, 2018), https://www.bbc.com/news/ world-asia-india-45988193.

139 Id.

$140 \mathrm{Id}$.

141 Id.

142 Manu Sebastian, CBI Director Cannot Be Divested of Powers Without Approval of High Powered Committee, Contends Alok Verma In SC, LiveLaw (Oct 24, 2018), https://www.livelaw.in/cbidirector-cannot-be-divested-of-powers-without-approval-of-high-powered-committee-contendsalok-verma-in-sc-read-petition/.

143 CBI Power Shift: Opposition Slams 'Illegal Removal' of CBI Chief Alok Verma, INDIAN EXPRESS (Oct. 25, 2018), https://indianexpress.com/article/india/cbi-power-shift-opposition-slams-illegalremoval-of-cbi-chief-alok-verma/.

144 Sunetra Choudhury \& Deepshikha Ghosh, Alok Verma Back As CBI Boss Without Powers As Court Scraps Centre's Order, NDTV (Jan. 08, 2019), https://www.ndtv.com/india-news/alok-vermareinstated-as-cbi-chief-by-supreme-court-he-was-sent-on-forced-leave-in-october-1974272. 
unceremoniously removed him from office by a two-to-one vote. ${ }^{145}$ The Supreme Court judge who added his vote to the Prime Minister to supply the majority had been offered an attractive post-retirement job by the government, ${ }^{146}$ an offer he rejected after media reports connected the two developments. ${ }^{147}$ Such was the level of distrust that two states forbade the CBI from conducting any investigations within their jurisdiction without their express permission. ${ }^{148}$

\section{Central Information Commission}

In 2005, India passed the Right to Information Act after a long-drawn social campaign led by civil society activists. ${ }^{149}$ The Act, aimed at increasing transparency and accountability, requires a timely response to citizen enquiries from "public authorities." 150 In order to oversee compliance and resolve disputes pertaining to information requests, the Act also establishes the office of Information Commissioners at both federal and state levels. The Commissioners have the powers of a civil court and can direct a public authority to disclose information it is legally required to disclose. ${ }^{151}$ In order to maintain their independence from the government, the commissioners' "salaries, allowances, and other terms and conditions" are protected by the Act. ${ }^{152}$

In 2014, after assuming office, the government entrusted the Commission's financial powers to a governmental department, which was restored to the Commission within a year, but only after protests by activists and opposition

145 Sunli Prabhu \& Debjani Chatterjee, “Very, Very Hasty Decision” on Alok Verma: Ex-Judge Who Monitored Probe, NDTV (Jan. 12, 2918), https://www.ndtv.com/india-news/justice-ak-patnaik-exsupreme-court-judge-says-no-evidence-of-corruption-against-alok-verma-1976618?pfrom=hometopscroll.

146 Maneesh Chhibber, Justice Sikri, Whose Vote Decided Alok Verma's Fate, Gets Modi Govt Mod for Plum Posting, PRINT (Jan. 28, 2019), https://theprint.in/governance/justice-sikri-whose-votedecided-alok-vermas-fate-gets-modi-govt-nod-for-plum-posting/177191/.

147 Krishnadas Rajagopal, Justice Sikri Refuses Offer from Government to Nominate Him to Commonwealth Tribunal, HiNDU (Jan. 13, 2019), https://www.thehindu.com/news/national/ justice-sikri-withdraws-consent-to-govt-offer-to-nominate-him-to-csat/article25986368.ece.

148 After Andhra Pradesh, West Bengal Withdraws 'General Consent' to CBI, TIMES OF INDIA (Nov. 16, 2018), https://timesofindia.indiatimes.com/india/after-andhra-pradesh-west-bengal-withdrawsgeneral-consent-to-cbi/articleshow/66657701.cms.

149 Aruna Roy, Excerpt: The RTI Story: Power to the People, Hindustan Times, (Apr. 13, 2018), https://www.hindustantimes.com/books/excerpt-the-rti-story-power-to-the-people-by-aruna-roywith-the-mkss-collective/story-V5AWqGRa84dCxyoVsR204L.html.

150 Right to Information Act, No. 22 of 2005, § 4.

151 Id. $\S 18$.

$152 I d . \S \S 13,16$. 
parties. ${ }^{153}$ Later, in 2018, the government introduced an amendment bill to give to itself significant discretion to determine salaries, perks, and tenures of the commissioners. ${ }^{154}$ The Commission continued to work seriously understaffed because of numerous unfilled vacancies. ${ }^{155}$ In its judgement in early $2019,{ }^{156}$ the Supreme Court castigated both the amendment and the failure to fill vacancies in order to frustrate the purposes of the Act, stating that:

By not filing up vacancies in information commissions in a timely manner, the Central and State Governments are frustrating the very purpose of the RTI Act as receiving information in a time-bound manner is the essence of the law. ${ }^{157}$

Notwithstanding this judicial reproach, the Modi Government saw the enactment of the Right to Information (Amendment) Act 2019 within a few months of the start of its second, more confident and less cautious, tenure. The transparency commission has been effectively downgraded from an autonomous fourth-branch quasi-constitutional body to a department of a governmental ministry.

\section{Senior Bureaucracy}

A non-partisan bureaucracy which can provide frank and fearless advice to the political executive is crucial for impartial implementation of laws and policies. The top bureaucracy in India is filled by senior officers initially selected by competitive examinations at the entry level, conducted by an independent constitutional body called the Union Public Services Commission. ${ }^{158}$ This system of appointments has, to some degree, protected civil services from political influence - although appointments to senior bureaucracy are indeed political, the pool from which candidates

153 Aloke Tikku, CIC’s Financial Powers Restored by Government, HinduSTAN Times (Aug. 1, 2015), https://www.hindustantimes.com/india/cic-s-financial-powers-restored-by-government/storyoBSX52JwNbR44qG4JvZqiN.html.

154 Vijayta Lalwani, 'Serious Attack': Activists Say Centre's Proposed Amendments Will Weaken RTI Act, SCROLL.IN (July 18, 2018), https://scroll.in/article/886927/serious-attack-activists-saycentres-proposed-amendments-will-weaken-rti-act; Nikhil Dey, Bhupender Yadav \& Bimal Julka, Has the Right to Information Act Been Weakened?, Hindu (July 27, 2018), https://www.thehindu. com/opinion/op-ed/has-the-right-to-information-act-been-weakened/article24523104.ece.

155 Madabhushi Sridhar, Apex Court Opposes Amendment to RTI, HANS India (Feb. 26, 2019), https://www.thehansindia.com/posts/index/Editorial/2019-02-25/Apex-court-opposes-

amendment-to-RTI/502185.

156 Bharadwaj v. Union of India, (2019) SCC OnLine SC 205.

157 Id. at 1 (Sikri J).

158 K. Ashok Vardhan Shetty, Lateral Entry into Senior Bureaucracy: A Flawed Approach, Hindu CTR. FoR POL. \& PUB. PoL'Y (July 11, 2018), https://www.thehinducentre.com/the-arena/currentissues/article24386653.ece. 
may be chosen has been limited and professional. ${ }^{159}$ However, the Modi Government introduced a direct lateral-entry system, calling upon "talented and motivated Indian nationals” from various professional backgrounds to apply for high-ranking positions in the federal government bureaucracy. ${ }^{160}$ Despite a specialized constitutional body for public services, the government retained the power of appointment for this parallel system to itself. Several commentators criticized this move as a return of the spoils' system in which civil service positions may be awarded to party supporters by bypassing the constitutionally mandated mechanism. ${ }^{161}$ Yet again, a move designed to facilitate the partisan capture of a state institution was justified in terms of managerial rationales such as efficiency and diversity of talent.

\section{National Statistical Commission}

The National Statistical Commission saw two of its members resign in protest after the government disallowed the publication of its report on unemployment. ${ }^{162}$ This left the Commission with only two remaining members, one of whom was an exofficio member. The leaked report allegedly reported skyrocketing unemployment figures under the Modi government. ${ }^{163}$

159 Id.

160 Government Opens Doors to Lateral Entry, Hindu (June 10, 2018), https://www.thehindu.com/ news/national/government-opens-doors-to-lateral-entry/article24130060.ece; Utpal Bhaskar, Nine from Outside the IAS Set to Become Joint Secretaries in Government, LIVEMINT (Apr. 13, 2019), https://www.livemint.com/politics/policy/nine-from-outside-the-ias-set-to-become-jointsecretaries-in-government-1555133560315.html.

161 K. Ashok Vardhan Shetty, Are We Ushering in the Spoils System in Senior Bureaucracy?, HINDU (June 19, 2018), https://www.thehindu.com/thread/politics-and-policy/lateral-entry-into-seniorbureaucracy-opening-the-flood-gates-for-a-spoils-system/article24201356.ece.

162 All Members of National Statistical Commission Resign after Centre Failed to Publish Jobs Report, SCROLL.In (Jan. 29, 2019), https://scroll.in/latest/911289/no-members-on-nationalstatistical-commission-after-resignations-over-centre-burying-jobs-report; Nikhil Menon, A Short History of Data, HINDU (Mar. 21, 2019), https://www.thehindu.com/opinion/lead/a-short-historyof-data/article26593687.ece?fbclid=IwAR2ynm-91DC7BoX2kAgw5MkvN_Vl11008Rsfloh8hZz67r ETmErDM6Ov2Uo.

163 Jeffrey Gettleman \& Hari Kumar, India's Leader is Accused of Hiding Unemployment Data Before Vote, N.Y. Times (Jan. 31, 2019), https://www.nytimes.com/2019/01/31/world/asia/indiaunemployment-rate.html. See generally Press Trust of India, 108 Economists from Around the World Object to 'Political Interference' in Statistics in India, Cite GDP and Job Data, News18 (Mar. 14, 2019), https://www.news18.com/news/business/108-economists-from-around-the-world-object-topolitical-interference-in-statistics-in-india-cite-gdp-and-job-data-2066997.html?ref=hp_top_pos_ 9. See also Raghuram Rajan Raises Questions about India's Growth Rate, Calls for Impartial Body to Clean Up Data, SCROLL.IN (Mar. 26, 2019), https://scroll.in/latest/917963/raghuram-rajan-raisesquestions-about-indias-growth-rate-calls-for-impartial-body-to-clean-up-data. 


\section{Reserve Bank of India}

The importance of the independence of the central bank to a democracy is especially noted by Lijphart in his classic work Patters of Democracy. ${ }^{164}$ He notes that "independent banks are widely considered to be better at controlling inflation and maintaining price stability than banks that are dependent on the executive." 165 The RBI is India's central bank and in charge of the country's monetary policy. While previous governments have had disagreements with the bank, they usually managed to reach compromises through negotiations behind closed doors. ${ }^{166}$ During Modi's tenure, the relationship between the government and the Bank was fraught with several public stand-offs, which soared after the government's demonetization policy (invalidating 86\% currency notes) was implemented without prior approval from the Bank. ${ }^{167}$ Other policy disagreements concerned interest rates, bad debt crisis of Indian public sector banks, setting up a separate regulator for payment wallets, and most importantly, cutting the RBI reserves. ${ }^{168}$ In 2016, the then independent-minded RBI Governor Raghuram Rajan resigned after it was made clear to him that he did not have the government's confidence. ${ }^{169}$ The government continued to clash on the issue of central bank reserves with his successor, Urjit Patel, who it itself had appointed.

164 Arend Lijphart, Central Banks: Independence versus Dependence, in PATTERNS OF DEMOCRACY: GOvERNMENT Forms \& PERFoRMANCE IN 36 Countries 226 (Arend Lijphart ed., second ed. 2010).

165 Id. at 20; see also Paul Tucker, Unelected Power: The Quest For Legitimacy In Central Banking And The Regulatory State (2018).

166 P. Vaidhyanathan Iyer, Urjit Patel: RBI Governor and His Governance, INDIAN EXPRESS (Nov. 4, 2018), https://indianexpress.com/article/india/governor-his-governance-rbi-urjit-patel-5433021/. 167 Anuj Srivas, Explained: The Widening Rift Between the RBI and the Modi Government, WIRE (Dec. 10, 2018), https://thewire.in/economy/explained-the-widening-rift-between-the-rbi-andthe-modi-government; Express Web Desk, PM Modi Went Ahead with Demonetisation Before RBI's Formal Approval: RTI, INDIAN EXPRESS (Mar. 11, 2019), https://indianexpress.com/article/ business/economy/demonetisation-pm-modi-rbi-board-urjit-patel-black-money-rti-5620929/.

168 Soutik Biswas, RBI: What is the Indian Central Bank's Conflict with the Government?, BBC (Nov. 1, 2018), https://www.bbc.com/news/world-asia-india-46054042.

169 Ellen Barry, Raghuram Rajan Says He'll Step Down as Head of India's Central Bank, N.Y. Times (June 18, 2016), https://www.nytimes.com/2016/06/19/business/head-of-indias-central-banksays-he-will-step-down.html. See generally Press Trust of India, Centralisation of Power One of India's Main Problems: Raghuram Rajan, NDTV (Nov. 10, 2018), https://www.ndtv.com/indianews/raghuram-rajan-centralisation-of-power-one-of-indias-main-problems-1945426. 
The level of governmental interference can be gauged by the highly unusual move of the Deputy Governor of the Bank, making a strong case for the independence of the central banks in a public speech in 2018. ${ }^{170}$ According to some commentators, the government's attack on the RBI's reserve was motivated by its political need to increase public spending on populist policies before the 2019 general elections. ${ }^{171}$ The government threatened to invoke its never-before-used statutory power to issue a binding directive to the RBI. ${ }^{172}$ The threat of the directive, and pressure from the government's allies packed into the Bank's board to corner the governor, ${ }^{173}$ forced a compromise of sorts where the government mostly got its way. ${ }^{174}$ Ultimately, Governor Patel also resigned. ${ }^{175}$ His successor, Shaktikanta Das, was a career bureaucrat, unlike his two economist predecessors. ${ }^{176}$ With a pliant governor finally in place, the RBI relented to fund the government's electionseason projects. ${ }^{177}$

170 Viral Acharya, Deputy Governor, Res. Bank of Ind., On the Importance of Independent Regulatory Institutions - The Case of the Central Bank, A. D. Shroff Memorial Lecture, Mumbai (Oct. 26, 2018), https://rbidocs.rbi.org.in/rdocs/Speeches/PDFs/ADSML51EEB918B7194BC6AA8B764B05006B15.PDF. 171 Mihir Swarup Sharma, Why RBI is Suddenly Standing Up To Modi - and What's at Stake, NDTV (Oct. 31, 2018), https://www.ndtv.com/opinion/what-modi-vs-rbi-is-all-about-its-an-electionyear-stupid-1940419?pfrom=home-opinion.

172 What is Section 7 of the RBI Act and Why This Extreme Step May See Urit Patel Call it Quits, News18 (Oct. 31, 2018), https://www.news18.com/news/business/what-is-section-7-of-the-rbi-actand-why-this-extreme-step-may-see-urjit-patel-call-it-quits-1925835.html.

173 Manoj Kumar \& Suvashree Choudhury, Narendra Modi Stacks RBI Board with Allies to Turn Heat up on Governor, WIRE (Nov. 18, 2018), https://thewire.in/government/narendra-modi-stacksrbi-board-with-allies-to-turn-heat-up-on-governor.

174 Mayer Shetty \& Surojit Gupta, Government Mostly Gets its Way, but RBI has a Deal it Can Live with, TIMES OF INDIA (Nov. 20, 2018), https://timesofindia.indiatimes.com/business/indiabusiness/government-mostly-gets-its-way-but-rbi-has-a-deal-it-can-live-with/articleshow/ 66700156.cms.

175 Urjit Patel Resigns as RBI Governor Amid Rift with Govt, PM Modi Says He'll be Missed 'Immensely', News18 (Dec. 10, 2018), https://www.news18.com/news/business/urjit-patel-stepsdown-as-rbi-governor-citing-personal-reasons-1967787.html; Urjit Patel's Exit is Another Sign of Modi's Limited Faith in Institutional Guidance, WIRE (Dec. 12, 2018), https://thewire.in/economy/ urjit-patels-exit-is-another-sign-of-modis-limited-faith-in-institutional-guidance.

176 Shaktikanta Das Appointed as the New RBI Governor, ECoN. TIMES (Dec. 13, 2018), https://economictimes.indiatimes.com/industry/banking/finance/banking/shaktikanta-dasappointed-as-the-new-rbi-governor/articleshow/67045353.cms.

177 Anirban Nag \& Vrishti Beniwal, RBI Gives Rs. 28,000 Crore Interim Dividend to Government Before Elections, NDTV (Feb. 18, 2019), https://www.ndtv.com/business/pm-modi-gets-rs-28-000crore-cash-from-central-bank-before-polls-1995406?pfrom=home-livetv. 


\section{Silencing Discursive Accountability Mechanisms}

While the independence of fourth branch institutions has some legal protection in India, the media, universities, and Non-Governmental Organizations (NGOs) that are critical to seeking diagonal accountability from the executive have been extremely vulnerable. The Indian judiciary has a mixed record of defending press freedom or academic freedom, and its free speech jurisprudence has been rather flexible. ${ }^{178}$ While every previous government has sought to control and influence these civil society institutions, the scale of the countrywide attacks - including violent attacks - on discursive institutions between 2014 and 2019 was unprecedented, excepting only the Emergency years under Indira Gandhi.

The BJP, its cultural-ideological mentor the RSS, and numerous sister organizations that help with political mobilization and supply politically-expedient violence with arm's-length deniability together constitute the Sangh Parivaar (the "family of the Sangh [RSS]"). The Sangh Parivaar has a long history of hostility to freedom of expression. Acting as a self-appointed censor, it has used legal, extralegal and illegal means to target artists, academics, journalists, and activists seen (through its expansive lens) as denigrating Hinduism or Indian culture. Even before the BJP's electoral victory in 2014, for example, Sangh Parivaar outfits managed to bully Penguin to recall and pulp a book titled "On Hinduism," authored by Wendy Doniger, a professor of religion at the University of Chicago. $^{179}$

What changed with power in 2014 was that the targets of its censorship came to include not only cultural and ideological enemies, but also political opponents, and the weapons became more potent. An academic, an activist, and a journalist were, for example, booked for sedition after protesting against a divisive bill seeking to amend India's citizenship law. ${ }^{180}$

178 See generally Rajeev Dhavan, Only the Good News: on the LaW of the Press In INDIA (1987);

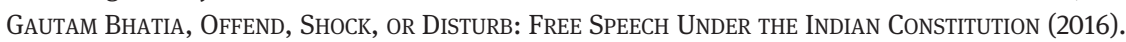
179 Soutik Biswas, Why Did Penguin Recall a Book on Hindus?, BBC (Feb. 12, 2014), https://www.bb c.co.uk/news/world-asia-india-26148875; Rama Lakshmi, The 'Ban Man': India's Self-Appointed Book Censor Wields Real Clout, WASH. Post (June 23, 2014), https://www.washingtonpost.com/ world/asia_pacific/the-ban-man-indias-self-appointed-book-censor-wields-real-clout/2014/06/ 23/6f71eca2-b73f-4102-96e0-21d5a52e59a7_story.html?utm_term=.79b8123123d0.

180 Abhishek Saha, Protest against Citizenship Bill: Assam Academic Hiren Gohain, Two Others Booked for Sedition, INDIAN EXPRESS (Jan. 11, 2019), https://indianexpress.com/article/north-eastindia/assam/assam-intellectuals-hiren-gohain-akhil-gogoi-manjit-mahanta-booked-for-seditionfor-remarks-on-citizenship-amendment-bill-5531915/. 


\section{A Attacks on Universities and Academic Freedom}

The University Grants Commission ("UGC") is a statutory body set up to set standards, promote and monitor higher education, and allocate grants to universities for the purposes of research, teaching and infrastructure. ${ }^{181}$ Although not completely independent, the UGC enjoys a limited degree of autonomy. For instance, its chairperson has a fixed tenure, ${ }^{182}$ and it does not normally need any authorization by the federal government regarding the exercising of its powers. $^{183}$

In June 2018, the government released the draft of a new legislation that would have overhauled the entire regulatory scheme for higher education. ${ }^{184}$ Under the draft bill, the new regulator would enjoy limited institutional autonomy. ${ }^{185}$ While this draft was shelved after protests, in the same year, the government issued a directive to public universities to implement Central Civil Services Rules for their employees. This meant that, like civil servants, academics employed by public universities would not be allowed to criticize the government or its policies. ${ }^{186}$ Amid severe protests that such measure would undermine academic freedom, the government declared that the directive was recommendatory, not mandatory. ${ }^{187}$ Similarly, the Union Ministry of Human Resource Development briefed ViceChancellors of central universities to "discourage research in irrelevant areas" and focus PhD research on "national priorities" instead, prompting the Central University of Kerala to draft an approved list of $\mathrm{PhD}$ topics. ${ }^{188}$ Using its executive powers, the government also withheld special funding from key universities,

181 University Grants Commission Act, No. 3 of 1956, § 12.

182 Id. $§ 6$.

183 Id. § 20.

184 The Higher Education Commission of India Bill, 2018 (Repeal of University Grants Commission Act, No. 3 of 1956).

185 Antara Sengupta, The Higher Education Commission of India bill: A Failure of Imagination, 5 (Observer Research Foundation, Issue Brief No. 252, 2018), https://www.orfonline.org/research/ 43521-the-higher-education-commission-of-india-bill-a-failure-of-imagination/.

186 Shuriah Niazi, Ministry Backpedals on ‘Gagging’ Rules for Academics, U. WorLd NEws (Oct. 26, 2018), http://www.universityworldnews.com/article.php?story=20181026124012244.

187 Id.

188 HRD Says PhDs Only on 'National Priority' Topics, Kerala Prof Quits Central Univ Board, InDIAN EXPRESS (Mar. 24, 2019), https://indianexpress.com/article/education/hrd-says-phds-only-onnational-priority-topics-kerala-prof-quits-central-univ-board-5639915/?

fbclid=IwAROtcmztNPZZhyVc4mHSbLxLOPFkQryk0phGAeOQeSjfkO9lfOPSSvWMBlo. 
allegedly for blatantly partisan reasons - basically, private universities whose patrons were seen as anti-Modi had their funding withdrawn. ${ }^{189}$

The government was also extremely enthusiastic in bringing sedition charges against students and academics for mere speeches. ${ }^{190}$ The Jawaharlal Nehru University in Delhi, a prestigious public university that has often been regarded as the bastion of left-wing ideology, especially drew the government's ire. A new university administration was put in place in 2016 to disrupt its internal functions, and, some claim, to compromise academic freedom. ${ }^{191}$ Five of its students were charged with sedition for protesting the execution of a Kashmiri separatist (and allegedly shouting "anti-India” slogans during the protest). The university itself was labelled "anti-national."192 This despite a Magistrate's report confirming that no such slogans were shouted: even if they were, the law on sedition is contravened only if the impugned speech has the tendency to incite violence. ${ }^{193}$ A well-known politics professor at the university, Nivedita Menon, faced prolonged vilification in the pro-government media for being "anti-national" after she publicly supported the students. ${ }^{194}$ Another university that was singled out was the Aligarh Muslim University. Fourteen of its students were booked for sedition after clashing with journalists from the pro-government television network Republic TV. ${ }^{195}$

189 Neelam Pandey, Intelligence Bureau Red-Flags PVT Universities Seeking Eminence Tag for Anti-Modi Patrons, THEPrint (Jan. 28, 2019), https://theprint.in/governance/intelligencebureau-red-flags-pvt-universities-seeking-eminence-tag-for-anti-modi-patrons/184151/?fbclid= IwAR1H1190SKOdET_ZgcLh8AfcYyU6soC-IWbQ_AIpW2UKDvXuLGnfzza2l_4.

190 See generally Nandini Sundar, Academic Freedom and Indian Universities, 53 Econ. \& PoL. WKLY. 16 (2018); Partha Chatterjee, Freedom of Speech in University, 51 ECon. \& PoL. WKLY. 35, 35-37 (2016).

191 Arunima G., The Battle for JNU's Soul, WIRE (Dec. 25, 2018), https://thewire.in/education/thebattle-for-jnu-soul.

192 Heena Kausar \& Shradha Chettri, JNU Row a Year Later: Kanhaiya to Khalid, How Lives of five Students Changed, Hindustan Times (Mar. 2, 2017), https://www.hindustantimes.com/ delhi-news/jnu-protests-a-year-on-how-the-feb-9-anti-national-event-changed-five-lives/story4jbNO1ByQtC9B8XbOMFFUK.html.

193 Despite SC's Stance on Sedition, Charge Slapped on JNU's Kanhaiya Kumar, Others, WIRE (Jan. 15, 2019), https://thewire.in/rights/despite-scs-stance-on-sedition-charge-slapped-on-jnuskanhaiya-kumar-others.

194 Jahnavi Sen, 'Vilification' of JNU Professor Nivedita Menon as 'Anti-National' Labelling Continues, WiRE (Mar. 15, 2016), https://thewire.in/politics/vilification-of-jnu-professor-niveditamenon-as-anti-national-labelling-continues.

19514 Aligarh Muslim University Students Booked for Sedition After Fracas with Republic TV Crew, SCROLL.IN (Feb. 13, 2019), https://scroll.in/latest/913063/14-aligarh-muslim-university-studentsbooked-for-sedition-after-fracas-with-republic-tv-crew. 
As in other spheres, the government took many small steps toward institutional capture in the education field - some invited vociferous protests or judicial intervention, and had to be rolled back. Others managed to stick.

\section{B Silencing Independent Media}

Governments and political parties using an imperfect guarantee of free speech to harass journalists is not new in India. What changed under the Modi regime was the scale, severity, and systemicity of these responses. ${ }^{196}$ The BJP maintains a comprehensive list of individual Indian journalists and classifies them as pro-BJP or anti-BJP. ${ }^{197}$ Instead of using the much-abused law against criminal defamation to silence journalists, even more diabolical colonial-era laws, such as the one criminalizing sedition, were deployed. ${ }^{198}$ In a system where the criminal process can take several years before a final verdict is arrived at, safeguards built into the substantive law lose much of their value: the process becomes the punishment. The Milli Gazette was harassed through the criminal process so much after it exposed an official policy of anti-Muslim discrimination in a government department that it felt compelled to end its print run. ${ }^{199}$ Media houses were pressurized, sometimes successfully, to let go of unbending editors. ${ }^{200}$ Some uncompromising editors, like Gauri Lankesh, were murdered by goons belonging to sister

196 Annie Gowen, In Modi's India, Journalists Face Bullying, Criminal Cases and Worse, WASH. Post (Feb. 15, 2018), https://www.washingtonpost.com/world/asia_pacific/in-modis-indiajournalists-face-bullying-criminal-cases-and-worse/2018/02/13/e8176b72-8695-42ab-abd5d26aab830d3e_story.html? noredirect $=$ on\&utm_term $=.83936 \mathrm{cfbc} 268$.

197 Ishita Mishra, Pro-BJP or Anti-BJP: Inside the Modi-Shah Media Tracking 'War Rooms', WIRE (Aug. 11, 2018), https://thewire.in/politics/narendra-modi-amit-shah-bjp-india-media.

198 See generally Niharika Banerjee, Centre "Trying to Silence Media" Unconstitutionally: Chandrababu Naidu, NDTV (Mar. 7, 2019), https://www.ndtv.com/india-news/centre-trying-to-silencemedia-unconstitutionally-chandrababu-naidu-2004199.

199 Gaurav Sarkar, The Curious Case of 'The Milli Gazette', NewsLaundRY (Feb. 14, 2019), https://www.newslaundry.com/2019/02/14/the-curious-case-of-the-milli-gazette.

200 Raju Gopalakrishnan, Indian Journalists Say They Are Intimidated, Ostracised if They Criticise Modi and the BJP, REUTERS (Apr. 26, 2018), https://uk.reuters.com/article/uk-india-politics-mediaanalysis-idUKKBN1HX1EO. 
organizations affiliated to the Sangh Parivaar. ${ }^{201}$ Self-censorship also grew - two large newspapers published and then removed stories on a report by Reporters Without Borders which had claimed that the Indian press had become less free under Prime Minister Modi. ${ }^{202}$

The CBI (an investigative agency that is, as we have already seen, tightly controlled by the government) conducted four simultaneous raids in the offices and residences connected to the news corporation, NDTV. While the CBI stated loan defaults as the ostensible reason for such raids, several senior media personalities, highlighting NDTV's anti-government stance, argued that the raids amounted to political harassment and that the government has not been so enthusiastic with its raids on other loan defaulters. ${ }^{203}$

The violence against the media was also expressive. A Minister in Modi's cabinet characterized journalists as "presstitutes."204 A major BBC report on fake news in India concluded that "[o]n the network analysis map produced during this research, we see that many more of the Twitter handles that have published fake news sit in the pro-BJP cluster, than in the anti-BJP cluster."205

All this is just what is in the public domain and may well be the tip of the iceberg. Behind-the-scenes attempts to capture or silence media organizations especially those that function outside the Delhi-centric national discourse - are very difficult to document, but are likely afoot. Discursive freedoms - never robust in India to begin with - suffered especially under the Modi regime. Conscious of the climate of hatred and violence being created, the former President Pranab

201 Gauri Lankesh: Indian Journalist Shot Dead in Bangalore, BBC (Sep. 6, 2017), https://www.bbc. com/news/world-asia-india-41169817; Jeffrey Gettleman \& Hari Kumar, In India, Another Government Critic is Silenced by Bullets, N.Y. TIMES (Sep. 6, 2017), https://www.nytimes.com/2017/09/06/world/ asia/gauri-lankesh-india-dead.html?module = inline; Rollo Romig, Railing Against India's RightWing Nationalism Was a Calling. It Was Also a Death Sentence, N.Y. Times MAGAZINE (Mar. 14, 2019), https://www.nytimes.com/2019/03/14/magazine/gauri-lankesh-murder-journalist.html?fbclid= IwAR2U1GRen4WjkOB2_Sm3Gwsdlb80sL5wZWYfpWkffMjk_Ug5EnaqXq3Rc9g.

202 The Hoot, The India Freedom Report: Media Freedom and Freedom of Expression in 2017, 17 (2001), http://asu.thehoot.org/public/uploads/filemanager/media/THE-INDIA-FREEDOM-REPORT. pdf; see generally 2019 World Press Freedom Index, REPORTERS wITHOUT BORDERS (2019), https://rsf. org/en/ranking.

203 Ellen Barry, Raids in India Target Founders of News Outlet Critical of Government, N.Y. TIMES (June 5, 2017), https://www.nytimes.com/2017/06/05/world/asia/india-ndtv-raids-narendra-modiprannoy-roy.html.

204 VK Singh in New Row, Calls Media 'Presstitutes', TIMES OF InDIA (Apr 8. 2015), https://timesofindia.indiatimes.com/india/VK-Singh-in-new-row-calls-media-presstitutes/ articleshow/46844032.cms.

205 Santanu Chakrabarti, Lucile Stengel \& Sapna Solanki, Duty, Identity and Credibility: 'Fake News' and the Ordinary Citizen in India 10 (2018), https://downloads.bbc.co.uk/mediacentre/dutyidentity-credibility.pdf. 
Mukherjee, before and since his retirement in 2017, made repeated public calls for greater tolerance in political discourse. ${ }^{206}$

\section{Confronting NGOs and other Civil Society Actors}

The Modi government vehemently repressed certain civil society organizations. It cancelled foreign contributions licences of more than $20,000 \mathrm{NGOs,}{ }^{207}$ making them ineligible to receive foreign funding. ${ }^{208}$ Some NGOs were in genuine violation of the law - for instance, by failing to submit their accounts. ${ }^{209}$ However, many of these licences were cancelled under a vaguely worded provision, which empowers the government to do so if such cancellation was "necessary in the public interest." 210 Many organizations against which this provision was used were engaged in human rights advocacy, frequently targeting the government for its human rights breaches. ${ }^{211}$ NGOs were raided, harassed, or worse, including reputed international ones like Amnesty and Greenpeace. ${ }^{212}$ While the government was harsh on civil society organizations, without a trace of irony it enthusiastically allowed foreign contributions to political parties, a move that mainly benefited the BJP.

206 President Pranab Mukherjee Stresses on the Need for Tolerance in Speech: Full text, FIRSTPOST (May 26, 2017), https://www.firstpost.com/india/president-pranab-mukherjee-stresses-on-theneed-for-tolerance-heres-the-full-text-of-his-speech-3482493.html.

207 Deya Bhattacharya, FCRA Licences of 20,000 NGOs Cancelled: Act Being Used as Weapon to Silence Organisations, FIRSTPost (Oct. 26, 2018), https://www.firstpost.com/india/fcra-licences-of20000-ngos-cancelled-act-being-used-as-weapon-to-silence-organisations-3181560.html.

208 Foreign Contributions Regulation Act, No. 42 of 2010, § 14.

209 Trilochan Shastri, NGOs, Foreign Funds and a Trust Deficit, Hindu (June 29, 2015), https://www.thehindu.com/opinion/op-ed/ngos-foreign-funds-and-a-trust-deficit/article7364282.ece. 210 Foreign Contributions Regulation Act, No. 42 of 2010, § 14(1)(c).

211 Amanat Khullar, FCRA and NGOs: What Lies behind the Government's Crackdown?, WIRE (Dec. 30, 2016) https://thewire.in/rights/fcra-ngos-lies-behind-governments-crackdown; AMNESTY INT’L, Suspension of Human Rights NGO's Foreign Funding Licence Must Be Revoked, AMNESTY INT'L INDIA (June 3, 2016), https://amnesty.org.in/news-update/suspension-human-rights-ngos-foreign-fundi ng-licence-must-revoked/.

212 ED Raids Amnesty India Over FEMA Irregularities: A Brief History of Centre's Crackdown on NGOs, FIRSTPOST (Oct. 26, 2018), https://www.firstpost.com/India/ed-raids-amnesty-india-overfema-irregularities-a-brief-history-of-centres-crackdown-on-ngos-5450341.html; Arvind Ojha, Raid at Greenpeace Office, ED Claims Evidence of Corruption, INDIA TODAY (Oct. 11, 2018), https://www.indiatoday.in/India/story/raid-at-greenpeace-office-ed-claims-evidence-of-corruption1360468-2018-10-11; ED 'Crackdown' Will Not Stop Our Fight against Climate Change: Greenpeace India, TIMES OF INDia (Feb. 2, 2019), https://timesofindia.indiatimes.com/india/ed-crackdown-willnot-stop-our-fight-against-climate-change-greenpeace-india/articleshow/67810498.cms?UTM_ Source=Google_Newsstand\&UTM_Campaign=RSS_Feed\&UTM_Medium=Referral. 
When Bollywood actor Aamir Khan raised concerns about the growing climate of intolerance in the country, ${ }^{213}$ the backlash that followed was vicious. ${ }^{214} \mathrm{~A}$ minister in the Modi government pretty much owned and justified this backlash, saying that "if anyone speaks like this, he has to be taught a lesson of his life."215 Activist Anand Teltumbde was arrested despite a Supreme Court order forbidding the state from doing so - he was released only after a lower court intervened to characterize the arrest as contempt of court. ${ }^{216}$

BJP-controlled state governments, which retain control of police powers, repeatedly used their powers of search and seizure against several other human rights and media organizations, who had taken a stand against BJP policies and actions. ${ }^{217}$ Going beyond search and seizure, the BJP-ruled state governments also used their police powers to arrest several human rights lawyers and activists, describing them as "urban Maoists."218 The BJP government in Assam brought 245 sedition cases in less than two years in power. ${ }^{219}$ Leaders of antireligious "rationalist" movements were murdered by Sangh Parivaar affiliates. ${ }^{220}$

213 Aamir Khan on Intolerance: I am Alarmed, My Wife Suggested Moving Out of India, ETIMES (Nov. 24, 2015), https://timesofindia.indiatimes.com/entertainment/hindi/bollywood/news/AamirKhan-on-intolerance-I-am-alarmed-my-wife-suggested-moving-out-of-India/articleshow/ 49897156.cms.

214 Soutik Biswas, What the Backlash against Bollywood's Aamir Khan Tells Us about India, BBC (Nov. 25, 2015), https://www.bbc.co.uk/news/world-asia-india-34918431.

215 Partha Sarathi Biswas, Parrikar Takes Swipe at Actor (Aamir): Those Who Speak Like This Must be Taught Lesson, INDIAN EXPRESS (July 31, 2016), https://indianexpress.com/article/india/indianews-india/parrikar-takes-swipe-at-actor-aamir-khan-intolerance-remark-those-who-speak-likethis-must-be-taught-lesson-2945440/.

216 Nitin Brahme \& Sukanya Shantha, Court Rules Anand Teltumbde's Arrest Illegal, Orders Immediate Release, WIRE (Feb. 2, 2019), https://thewire.in/rights/court-orders-anand-teltumbdesarrest-illegal.

217 Income Tax Officials Leave The Quint's Office in Noida after 22 h, SCROLL.In (Oct. 11, 2018), https://scroll.in/latest/897830/income-tax-officials-visit-the-quints-office-in-noida-and-founderraghav-bahls-home; Krishna N. Das, Amnesty India Says Raid, Frozen Accounts Aimed at Silencing Government, N.Y. TimEs (Oct. 26, 2018), https://www.nytimes.com/reuters/2018/10/26/world/asia/ 26reuters-india-amnesty.html.

218 Mahtab Alam \& Neha Mehrotra, There Is No Disputing the 'Emergency-Like' Situation in the Country, WIRE (July 29, 2018), https://thewire.in/government/there-should-be-no-debate-aboutthe-countrys-emergency-like-situation.

219 Abhishek Saha, 245 Sedition Cases in Assam under New Govt, INDIAN EXPRESS (Feb. 5, 2019), https://indianexpress.com/article/north-east-india/assam/245-sedition-cases-in-assam-under-newgovt-5569142/.

220 Soutik Biswas, Who killed Dr Malleshappa Kalburgi?, BBC (Aug. 31, 2015), https://www.bbc. com/news/world-asia-india-34105187. 
Muslim citizens were lynched for allegedly possessing or consuming beef, ${ }^{221}$ which inspired over fifty film-makers, writers, and others to return their national awards in protest. $^{222}$ Despite several allegations against Hindu nationalist groups, the federal and state governments were unable or unwilling to check, punish, credibly investigate, or even condemn vigilante violence. ${ }^{223}$ In fact, many BJP lawmakers publicly expressed support for some of these groups. ${ }^{224}$

It is the extensive use of violence and criminality against discursive actors that distinguishes democratic deconsolidation in India from similar efforts elsewhere, chiefly Hungary and Poland.

\section{Conclusion}

The BJP government incrementally but systemically attacked nearly all existing mechanisms that are in place to hold the political executive to account, either by ensuring that these mechanisms became subservient to the political executive or were captured by party loyalists. Almost all the techniques of what Sadurski calls the 21st century authoritarian's "playbook" were deployed. ${ }^{225}$ Section II shows that the electoral level-playing field was skewed to give the ruling party an advantage. In Section III, we see that the political Opposition was constrained, especially by targeting the offices and institutions in which it still held sway (such as the upper chamber in the federal parliament, state governments it controlled, and the office of the Leader of Opposition). Section IV outlines the government's attack on

221 Soutik Biswas, Is India Descending into Mob Rule?, BBC (June 26, 2017), https://www.bbc.com/ news/world-asia-india-40402021; Helen Regan \& Swati Gupta, Indian Authorities Failed to Stop 'Cow Vigilante' Violence: Report, CNN (Feb. 21, 2019), https://edition.cnn.com/2019/02/20/asia/ india-cow-vigilante-hrw-report-intl/index.html. On the rise of majoritarian violence under Modi, see Manoj Mate, Constitutional Erosion and the Challenge to Secular Democracy in India, in Constitutional Democracy IN CRISIs? ch. 22 (Mark A. Graber, Sanford Levinson, \& Mark Tushnet eds., 2018).

222 Ajay Gudavarth, India After Modi: Populism And The Right 22 (2018); Remove BJP, "Protect Democracy”, Say 100 Filmmakers in a Joint Statement, NDTV (Mar. 29, 2019), https://www.ndtv. com/india-news/remove-bjp-protect-democracy-over-100-filmmakers-in-a-joint-statement2014866?pfrom=home-topstories.

223 Human Rights Watch, India: Unchecked Attacks on Religious Minorities, Human Rights Watch World Report (Jan. 18, 2018), https://www.hrw.org/news/2018/01/18/india-unchecked-attacksreligious-minorities.

224 Id.

225 WojCiech SADURSKi, Poland's Constitutional BREAKdown 269-70 (2019). For a documentation of some of the early moves in this direction by the first Modi regime, see ARUN THIRUVENGADAM, THE Constitution of India: A ConTeXtual ANALYSIS 235-40 (2017). 
(ideally) non-partisan accountability-seeking institutions, such as the judiciary and fourth branch bodies. Section V details its silencing of discursive bodies, such as the media, universities, and NGOs. The combined reading of all these efforts makes it very difficult to deny a systemic blueprint to comprehensively secure executive aggrandizement and party-state fusion in India. With multiple small steps, the state is being identified with the party, and patriotism with the BJP's narrowly-defined majoritarian nationalism. ${ }^{226}$ Opponents of the party are being labelled anti-national, or traitors, ${ }^{227}$ and independent institutions billed as ineffective, corrupt, and inefficient. An ostensible developmental agenda was used to justify the defanging of institutions that allegedly got in the way of delivering welfare to the people.

The tools for inflicting the thousand cuts differed. Measures that sought to undermine electoral accountability chiefly sought legislative or constitutional change. On the other hand, while some assaults on the institutional accountability mechanisms were indeed sought through legal and constitutional change, many of them pushed against established precedents, practices, and ways of doing things that were not necessarily illegal, but certainly a breach of constitutional civility or comity. ${ }^{228}$ Many of these acts were not so much unconstitutional (although some clearly were), but constitutionally shameless. By claiming to be the sole repository of legitimate state power, the political executive refused to respect any autonomous zone of operation for other state institutions. Attacks on discursive institutions were either plainly violent and illegal, or used the protracted and often draconian criminal law process itself as punishment. While the constitutional and legislative changes that succeeded are likely to be stickier, other actions of the government also created precedents for future administrations to cite in legitimizing their own excesses - just as this government cited the excesses of its own predecessors even as it scaled them up to new levels of abuse.

The Constitution was being killed with a thousand cuts. This became possible in part because of some original design flaws in the Constitution (such as the centrally appointed office of the Governor and the inadequate protection of opposition rights), the failure of key institutional watchdogs to do their duty, and political failure of the Opposition to launch a united resistance. Responding to these multiple, small-scale, incremental assaults is very difficult for checking

226 See generally Sten Widmalm, Under Modi Govt, a Two-Pronged Attack on India's Democracy, WIRE (Apr 07, 2019), https://thewire.in/politics/india-democracy-modi-government.

227 Manish Kumar, Those Who Skip PM Rally Are Traitors, Said Giriraj Singh. Then He Bunked, NDTV (Mar. 04, 2019), https://www.ndtv.com/india-news/bjp-leader-giriraj-singh-calls-thosewho-miss-pms-rally-traitors-he-also-bunks-2002513?pfrom=home-topstories.

228 Tushnet, supra note 48; Timothy Endicott, Comity Among Authorities, 68 CURRENT LEGAL PROBS. 1 (2015). 
institutions. Seen in isolation, each assault is relatively unthreatening to the constitutional scheme taken as a whole, especially when many of these abuses have been inflicted on the Constitution by previous governments as well. What set them apart was their systemicity - that so many of them were launched against constitutional institutions simultaneously and in an evidently choreographed fashion. $^{229}$

None of this is to deny the resistance that the government faced, from state institutions as well as from the political opposition and discursive organizations. Many of its attempts on the Constitution failed precisely because of this resistance. ${ }^{230}$ But there is need to take stock of the political and institutional weaknesses in the Indian constitutional scheme that allowed or facilitated a lot of this to happen. Indira Gandhi's excesses in the 1970s were undone politically, because she lost the general elections in 1977 to a united opposition, allowing the shortlived Janata Party government to reverse her authoritarian moves by the Constitution (44th Amendment) Act 1978. Narendra Modi, on the other hand, not only won, but increased his majority, in the 2019 general elections. In the early days of his second regime, it appears that his government has given up on the incremental techniques for constitutional evisceration that were a hallmark of his first term in office. Not only has the government moved swiftly to enact and concretize some of its proposals from its first term, it has also thrown caution to the wind by downgrading Kashmir's constitutionally-guaranteed autonomous status following a preposterous procedure, effectively amending the Constitution through executive action. $^{231}$

Ultimately, the three modes of seeking executive accountability ensure that today's political losers can be tomorrow's winners. They provide political insurance to the losing side, giving them hope of future victories, and thereby securing their consent to play by the rules of the democratic game and resolve disputes politically rather than violently. ${ }^{232}$ Undermining democratic checks ultimately risks authoritarianism, and is therefore inefficient as well as unpatriotic. The people of India publicly and communally reciting the Preamble to their

229 See generally Why Modi Must Go, NAT’L HERALD (Mar. 16, 2019), https://www.national heraldindia.com/opinion/why-modi-must-go-2?fbclid=IwAR0zrg_Utv91ePUjYrGuRtOG6k19attdV20 RCfZlgaYHzBj02GHtdFE21Ws.

230 See generally Meghna Yadav, Even Under Attack, India's Democratic Institutions Are Pushing Back, WIRE (Mar. 11, 2019), https://thewire.in/government/modi-government-pushback-democraticinstitutions.

231 Balu Nair, Abrogation of Article 370: Can the President Act without the Recommendation of the Constituent Assembly?, 3 Indian L. Rev. 254 (2019).

232 Ros Dixon \& Tom Ginsburg, The Forms and Limits of Constitutions as Political Insurance, 15 INT’L J. CONST. L. 988 (2017). 
Constitution in continuing protests that have erupted across the country since December 2019 appear to understand this, even as India's dithering institutions fail to grasp the enormity of the stakes, or are unable or unwilling to do very much about it.

Acknowledgments: I am grateful for helpful comments from several colleagues, too numerous to be named here. Many thanks to Aradhya Sethia, Rishabh Bajoria, and Dilara Ozer for excellent research assistance, and to Robin Gardner, Ken Kiat, and Nick Gillies for help with checking and formatting references. 


\section{University Library}

\section{- M M N E R VA A gateway to Melbourne's research publications}

Minerva Access is the Institutional Repository of The University of Melbourne

Author/s:

Khaitan, $\mathrm{T}$

Title:

Killing a Constitution with a Thousand Cuts: Executive Aggrandizement and Party-state Fusion in India

Date:

2020

\section{Citation:}

Khaitan, T. (2020). Killing a Constitution with a Thousand Cuts: Executive Aggrandizement and Party-state Fusion in India. Law and Ethics of Human Rights, 14 (1), pp.49-95. https:// doi.org/10.1515/lehr-2020-2009.

Persistent Link:

http://hdl.handle.net/11343/241852 